\title{
From tree to architecture: how functional morphology of arborescence connects plant biology, evolution and physics
}

\author{
Anita Roth-Nebelsick ${ }^{1}$ (D) Tatiana Miranda ${ }^{2} \cdot$ Martin Ebner $^{2} \cdot$ Wilfried Konrad ${ }^{2,3} \cdot$ Christopher Traiser $^{2}$
}

Received: 28 January 2020 / Revised: 4 May 2020 / Accepted: 24 September 2020 / Published online: 7 January 2021

(C) The Author(s) 2021

\begin{abstract}
Trees are the fundamental element of forest ecosystems, made possible by their mechanical qualities and their highly sophisticated conductive tissues. The evolution of trees, and thereby the evolution of forests, were ecologically transformative and affected climate and biogeochemical cycles fundamentally. Trees also offer a substantial amount of ecological niches for other organisms, such as epiphytes, creating a vast amount of habitats. During land plant evolution, a variety of different tree constructions evolved and their constructional principles are a subject of ongoing research. Understanding the "natural construction" of trees benefits strongly from methods and approaches from physics and engineering. Plant water transport is a good example for the ongoing demand for interdisciplinary efforts to unravel form-function relationships on vastly differing scales. Identification of the unique mechanism of water long-distance transport requires a solid basis of interfacial physics and thermodynamics. Studying tree functions by using theoretical approaches is, however, not a one-sided affair: The complex interrelationships between traits, functionality, trade-offs and phylogeny inspire engineers, physicists and architects until today.
\end{abstract}

Keywords Trees $\cdot$ Xylem $\cdot$ Water transport $\cdot$ Branching structure $\cdot$ Soil-plant-atmosphere continuum $\cdot$ Epiphytes

\section{Introduction}

Functional morphology employs to a great deal physical principles to analyse functional capacities of structures in relation to environment and to evaluate the expected benefit for the organism. Methods and insights from engineering sciences, mathematics and physics were used early on to study functional features of plant traits (a comprehensive survey of literature can be found in the review of Moulia 2013; for a survey of the history of biomechanics see Geitmann et al. 2019). The ancient and widely established use of wood or other lignified plant tissues

This article is a contribution to the special issue "Palaeobotanical contributions in honour of Volker Mosbrugger"

Anita Roth-Nebelsick

anita.rothnebelsick@ smns-bw.de

1 State Museum of Natural History, Rosenstein 1, 70191 Stuttgart, Germany

2 Department of Geosciences, University of Tübingen, Hölderlinstr. 12, 72074 Tübingen, Germany

3 Institute of Botany, Technical University of Dresden, Zellescher Weg 20b, 01217 Dresden, Germany or organs, such as bamboo stems, rattan and many other for buildings, boats, furniture and other products enhanced the perceived connection between plant bodies and technical constructions (Wegst et al. 2015). Besides material aspects of building and construction, plant structures influenced also designers and architects. Antique columns, for example, were often decorated with floral ornaments. A famous and more recent case is plantbased aesthetics in Art Nouveau and Art Deco where ornaments and patterns drew heavily from plant models (Fig. 1a). Recent developments are attempts in architecture to combine the natural aesthetics of wood and other plant material with principles from functional morphology (Menges and Reichert 2015; Knippers et al. 2019).

Progress in functional morphology depends on progress in methods derived from physics, mathematics and engineering sciences. For example, the development of numerical methods in applied mathematics and engineering sciences to analyse mechanical behaviour of structures via finite elements contributed substantially to the study of plant stem mechanics (Niklas 1997; James et al. 2014). Ongoing progress in methods for structure analysis and imaging, such as cryo scanning electron microscopy, micro-CT or AFM (atomic force microscopy), has considerably expanded the possibilities for plant structural research during the last decades, leading to new discoveries 

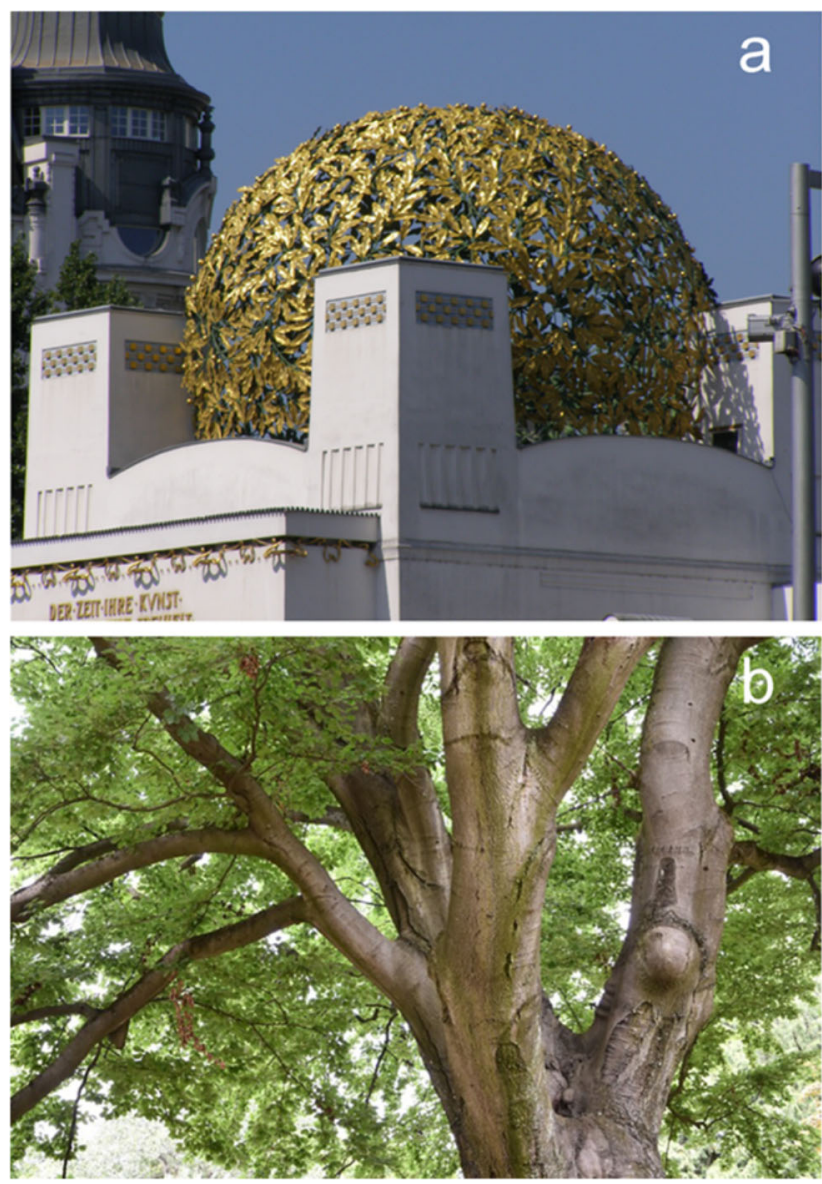

Fig. 1 Plant-derived inspirations in architecture. (a) "Canopy-like" dome of the Secession Building, Vienna, Austria (image: $j k b$. Licence: CreativeCommons by-sa-3.0-de. Link to Original file: https://commons. wikimedia.org/wiki/Category:Secession_Hall_(Austria)?uselang=de\#/

and perspectives (Koch et al. 2004b; Pesacreta et al. 2005; Brodersen et al. 2011; Gorb et al. 2013; Hesse et al. 2019; Kaack et al. 2019). It is not surprising that plants are a rich source of biological examples for the relationship between form and function in biomimetics, an interdisciplinary field of work which aims at identifying functional principles from biology which are suitable for transfer into technical solutions (Fratzl 2007). The interest of engineers and physicists in plants is not limited to systems of mechanical stabilisation, but comprises numerous other aspects, such as biofluid dynamics and surface effects.

In palaeobotany, plant functional morphology is essential as the basis for reconstructing plant habit and life style. Understanding land plant evolution requires information on functional and environmental constraints which can only be obtained indirectly, on the basis of physical and physiological relationships. For example, approximating the height and stability of trees derived by physical principles applied to the morphology and anatomy of fossil remains is of central importance to reconstructing a forest system (Mosbrugger 1990). In combination with ecophysiology, functional morphology

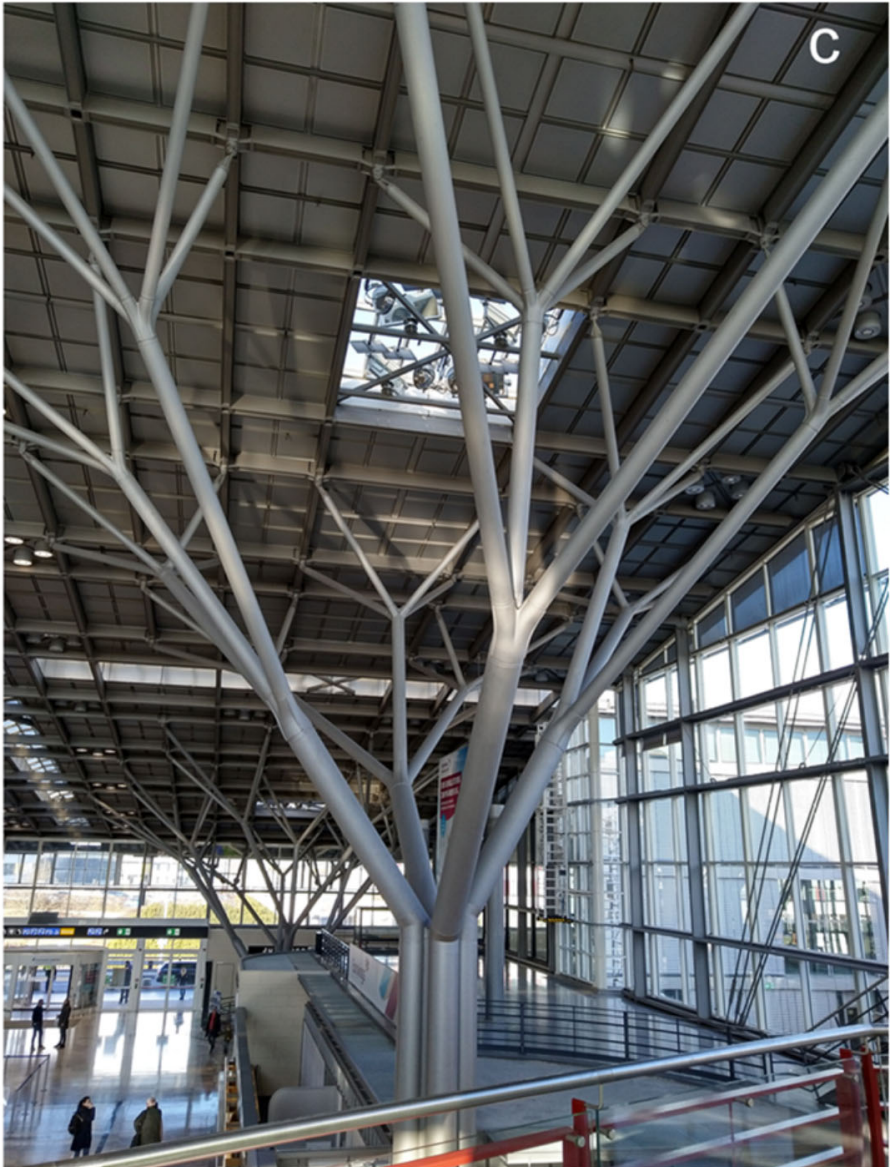

media/File:Kuppel_Wiener_Secession.jpg). (b) The impressive and mechanically robust branching systems of trees (Fagus sylvatica) inspired various artificial supporting structures in architecture, such as the steel 'tree' columns which support roofs of the Stuttgart airport (c)

allows for evaluating productivity and viability of plants under past climate conditions. An example here are the effects of environmental conditions of the geological past, such as atmospheric composition, on the ecophysiology of fossil plants which need to be studied by theoretical approaches (DiMichele and Gastaldo 2008; Raven and Edwards 2014; Raven 2017).

Trees are the largest multicellular organisms, and the evolution of trees and forests was ecologically transformative on a global scale (Morris et al. 2015). It is well established that forestation of the continents during the Paleozoic altered the earth system in terms of radiation budget, carbon budget and water cycling. Trees and forests provide numerous habitats for other organisms as can also be demonstrated for the distant past (Rößler 2000; Spindler et al. 2018). Consequently, deforestation - as is recently occurring due to anthropogenic influence - affects climate and biochemical cycles. The substantial height of trees and their ability to carry massive crowns are made possible by complex and fascinating tissues serving stabilisation, supply with water and nutrients and the connection between the crown and subterranean parts. 
Whereas modern forests are dominated by trees belonging to conifers and dicots with their stems representing more or less massive secondary wood columns, the diversity of tree stem structures was considerable higher in the past. Due to their complex and diverse functional aspects, trees are particularly suitable for applying methods and concepts from engineering and physics, as will be discussed in this contribution.

\section{The tree-a multifunctional affair}

The evolution of land plants, including mosses, liverworts and the various groups of vascular plants, produced a vast diversity of body plans, structures and ecological strategies for occupying numerous niches. An important step was the evolution of the tree growth form which appeared quite early during land plant evolution, with fossil forests dating back to the Middle Devonian (Stein et al. 2012; Stein et al. 2020). By the end of the Devonian, all principal plant body plans were established (Bateman et al. 1998) including the "modern" tree stem, as represented by Archaeopteris, consisting of a massive column of secondary wood (Meyer-Berthaud et al. 1999; Meyer-Berthaud et al. 2010; Decombeix et al. 2011). One of the first questions that come into mind when seeing a tall tree is how this biological construction is mechanically stabilised. Trees can be considered as upright columns which are fixed at one end. The mechanical stability of such objects depends on various parameters, such as length, diameter, cross-sectional shape, tapering and mechanical loading. Also, the mechanical qualities of a tree trunk depend on the material parameters of the tissues making up the stem and on their distribution. Supporting material should be particularly concentrated at critical positions, i.e. the base and the stem periphery. Basics of tree biomechanics as well as the various reasons and mechanisms of mechanical failure of trees are described in detail in Mosbrugger (1990) and Niklas (1992). From such concepts, which are rooted in engineering sciences, a multitude of different analyses considering habit and life style of fossil plants is possible, such as, for example, the height of fossil trees (Mosbrugger 1990), their growth form, i.e. to distinguish between lianas and self-supporting plants as well as changes in mechanical qualities during ontogeny (Rowe and Speck 2005).

The fossil record as well as extant vegetation show that trees can be constructed in quite different ways (Mosbrugger 1990). The stabilising trunk of trees can be composed of a massive column of secondary wood, as in conifers and dicot trees, or can be represented by a hollow cylinder stabilised by a peripheral layer of lignified tissue, such as in fossil arborescent equisetopsidae (Cichan and Taylor 1983; Cichan 1986), or, furthermore, can achieve stability on the basis of other tissues. This is demonstrated by various plant groups such as tree ferns, in which a mantle of aerial roots is involved in mechanical support, or the stabilising role of leaf bases in Medullosa, a pteridosperm. Each constructional tree type represents different biomechanical concepts (Niklas 1997).

Tree-like plants lacking secondary wood can employ quite fascinating strategies for mechanical stabilisation. For example, stabilisation in arborescent fossil seed plants was achieved by special cortex layers, as exemplified by the pteridosperm Lyginopteris oldhamia (Masselter et al. 2017). Similar structures within the bark for stabilisation can also be found in the extant dicot species Carica papaya (Caricaceae), the papaya, and Ochroma pyramidale (Malvaceae), known as the balsa tree. For both taxa, wood plays a quite minor mechanical role (in the case of C. papaya, secondary wood, according to the botanical definition, is even lacking). Rather, the stem is stabilised to a large degree by a fibre system within the secondary phloem (Fisher and Mueller 1983; Kempe et al. 2014). These special fibre systems, fossil and recent, probably operate in quite the same manner like a "trellis" system (Poppinga and Speck 2019). There is ongoing progress in understanding plant stem constructions, and evidence was found recently that bark can also substantially contribute to mechanical behaviour in dicot trees (Clair et al. 2019).

An important element of tree architecture (and plant body plans in general) is branching, with various different ramification patterns that appeared during land plant evolution (Kenrick and Crane 1997; Meyer-Berthaud et al. 2000; for a recent review, see Chomicki et al. 2017). Since most plant body plans include branching, including taxa with and without secondary wood, the support of a branched system is an important mechanical problem for trees. Tree-like plants lacking secondary wood can employ quite complex strategies for mechanical support of branches. The axis of the monocotyledonous tree-like Dracaena reflexa (Asparagaceae) is composed of partially lignified parenchyma which contains vascular bundles, arranged in a spirally winding manner (Schwager et al. 2010). After injury, branching starts from dormant buds, often with the die-back of the quite thin initial main stem shortly above the ramification. These branches are mechanically supported by a special "flange-mounted" structure, built by newly formed stem-clasping fibres (Schwager et al. 2010).

Branched columnar structures are also widespread in architecture, and various constructions were inspired by trees (Cui et al. 2016) (Fig. 1b, 1c). Despite their often tree-like appearance, the mechanical concept of ramified artificial constructions mostly differs, however, markedly from that of trees. For example, branches in gymnosperms and dicot trees are usually deeply embedded in the main trunk, and adaptive secondary growth optimizes the shape of the junction region (Müller et al. 2006). Additionally, fibre arrangement and prestressing are essential for the biomechanical qualities of a tree trunk construction (Speck and Burgert 2011; Born et al. 2016). Wood and other fibrous plant tissues have high tensile but a low compressive strength which can be markedly improved 
by prestressing of peripheral fibres. Prestressing is generated during cell differentiation due to interactions on the level of macromolecules within the cell walls which lead to a shortening tendency of single cells. This is counteracted by adjacent cells and leads to stress within the tissue, finally leading to prestressing (Yamamoto et al. 2002). The diversity of strategies and structures for mechanical stabilisation that can be found in tree stems are an attractive resource for building constructions and the analysis of the stability of trees, or of other plant growth forms, is in fact a good example how both engineering sciences and functional anatomy/morphology benefitted in a mutual way from interdisciplinary cooperation. For example, new concepts for fibre-reinforced composites which include branched structures are developed inspired by fibre support systems of plants (Speck et al. 2018).

The ultimate benefit of the tree habit is the exposure of a leafy crown to as much light as possible (representing a 'meadow on stilts', Christian Körner, pers. comm.). The tree stem allows its assimilating leafy parts to invade much more space than would be possible for herbs. The spatial separation between water and nutrient absorption from the soil by subterranean roots and photosynthesis taking place in the canopy demands an efficient long-distance transport system, which is another crucial functional aspect of the tree habit. The tree stem has to provide not only mechanical stability but also contains long-distance transport pathways, represented by xylem (water transport) and phloem (transport of sugars). In the herbaceous state (and in leaves), both tissue types are integrated together into vascular bundles, but become separated during secondary growth, with secondary wood being responsible for water conduction whereas the bark contains the secondary phloem. Despite this separation, transport in the xylem and the phloem is connected via water exchange (Jensen et al. 2012; Konrad et al. 2018). In the interesting case of fossil arborescent lycopsids, secondary wood was produced, but secondary phloem was missing (Eggert and Kanemoto 1977). This absence of secondary phloem has raised questions on the ecophysiology of lycopsids (Boyce and DiMichele 2016). There is, however, evidence for high productivity in arborescent lycopsids (Cleal and Thomas 2005; Wilson et al. 2017)

The tree stem is therefore a "lifting system" as well as a supply system which transports water and nutrients to the assimilating leaves. Leaves - in the sense of megaphyllsappeared in four plant lineages during the Paleozoic (Boyce and Knoll 2002) and are probably derived from a lateral branch system via various processes whose details are still discussed (Beerling and Fleming 2007; Galtier 2010; Vasco et al. 2016; Harrison and Morris Jennifer 2018). The third component is the root system which provides anchorage and absorbs water and nutrients from the soil (Ennos 2000). Roots form subterranean systems which can attain impressive dimensions (as indicated by the title of a book dedicated to all aspects of plant roots: "Roots - the hidden half" (Eshel and Beeckman 2013)). Roots evolved during the Devonian and represented a transformative element for both plant construction and the biogeochemical cycle (Morris et al. 2015).

\section{Between earth and sky-the soil-plant-atmosphere continuum}

The largest part of the water transported in the xylem serves the transpiration stream which is driven by evaporation of water from stomata which have to be open to allow for $\mathrm{CO}_{2}$ uptake required for photosynthesis. The inevitable coupling of water loss by transpiration and $\mathrm{CO}_{2}$ uptake means that transpiration is the price that land plants have to pay for photosynthesis. The amount of transpired water depends on the total leaf surface, the average leaf conductance (mostly dominated by stomatal conductance) and the air humidity. Together with the soil as the ultimate water source, uptake of water by roots, xylem sap flow and transpiration form a transport catena which finally ends in the atmosphere, receiving the evaporated water. Besides conducting water to the transpiring leaves, the transpiration stream also carries nutrients, making it difficult to completely separate the "pure" water demand by assimilating leaves from the demand for nutrients which are also transported in the transpiration stream (Tanner and Beevers 2001; Cramer et al. 2009).

This catena of pathways conducting water from the soil to the atmosphere, with a phase change from the liquid phase to the vapor phase taking place within intercellular spaces of the leaf (Rockwell et al. 2014), is termed soilplant-atmosphere continuum ("SPAC") (Fig. 2) (Passioura 1982; Sperry et al. 2003; Manzoni et al. 2013). The single elements of this pathway contribute different hydraulic conductivities and the transport through the entire catena can be treated as a network of single resistances analogous to treating a network of electrical resistances according to Kirchhoff's rules (Kramer 1983). The amount of water vapor ejected by land plants, and particularly forests, are huge, making them important elements of the water cycle (Jasechko et al. 2013). Leaves represent "gas exchangers", absorbing $\mathrm{CO}_{2}$ from the atmosphere, while transpiring water vapor (and emitting $\mathrm{O}_{2}$ and other gases). The capacity of the leaf conducting system, the venation, for water transport is therefore essential. Angiosperm leaves are particularly efficient in water transport, and it was argued that the evolution of angiosperm leaves represented a major event in the hydrological cycle (Boyce et al. 2009; Boyce et al. 2010). Additionally to water transport, the leaf venation serves various other tasks (Roth-Nebelsick et al. 2001; Sack and Scoffoni 2013) which are the object of ongoing research (Sack et al. 2016; Blackman et al. 2018). 


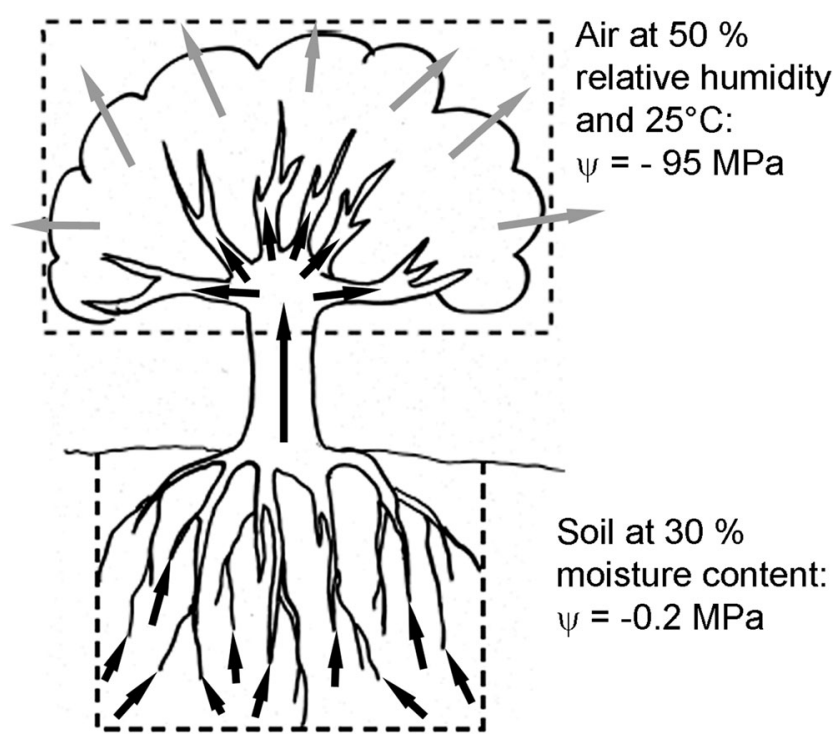

Fig. 2 Schematic representation of the soil-plant-atmosphere continuum (SPAC), under conditions of daylight when stomata are open and assimilation is running. Arrows indicate the flow of liquid water (black, through soil and plant) and of water vapour (grey, from the leaf interior to the atmosphere). For the soil, typical values for clay loam were provided (Kramer and Boyer 1995) (drawing by Birgit Binder, Entringen)

Transpiration can be understood as cost of photosynthesis, with the plants "paying" for carbon assimilation by water. The water use efficiency (WUE), meaning the amount of water that was transpired per unit of carbon assimilated, is an often used indication of how "expensive" assimilation is. Water vapor loss due to gas exchange depends not only on stomatal conductance, but also on external humidity, or, to be more precise, on the difference between leaf external air humidity $\left(v_{\text {ext }}\right)$ and leaf internal air humidity ( $\left.v_{\text {leaf }}\right)$ which is usually close to saturation $\left(v_{\text {sat }}\right)$. Evaporation $(E)$ from a leaf can therefore be described by

$E=g_{\text {leaf }}\left(v_{\text {ext }}-v_{\text {leaf }}\right)$

with $g_{\text {leaf }}=$ leaf conductance, which comprises stomatal conductance as well as boundary layer conductance (Nobel 2005). Usually, $g_{\text {leaf }}$ is dominated by stomatal conductance, but boundary layer conductance can become (co-)limiting under certain circumstances (thick boundary layer due to large leaf size and/or calm wind conditions, particularly when combined with large stomatal conductance).

Transpiration rate under a given stomatal (or leaf) conductance depends therefore on air humidity, meaning that it is favourable for plants to maximize stomatal aperture under moist air conditions. In fact, plants tend to open their stomata precisely under those conditions, leading to a typical diurnal profile with high stomatal conductance during the morning (when temperature is low and air humidity therefore high) and lower stomatal conductance during the rest of the day (when temperature is higher and air humidity therefore lower) (Larcher 2003). In economic terms, plants try to "buy" carbon when it is "cheaper" in terms of water costs. These depend also on water availability in the soil, and stomatal conductance also declines with decreasing soil humidity (Larcher 2003). From these considerations, the stomatal control can be described as optimising assimilation ( $=\mathrm{CO}_{2}$ uptake) against water loss (=transpiration), which is achieved by continuously responding to fluctuating environmental conditions.

Despite the stomatal control system, evaporation rates from tree canopies are immense. Sufficient water supply to a crown of transpiring leaves therefore requires an efficient transport system. The driving force for water flow is transpiration at the leaves, meaning that generally no metabolic energy is invested in water transport (with some exceptions, such as root pressure during spring in deciduous dicot trees and lianas). This "passive" water transport occurring upwards in high trees for which the length of the transport path can be considerable, reaching up to about $100 \mathrm{~m}$ in height, poses a special problem, namely the threat of cavitation and blockage of the xylem conduits by embolism. This topic has received much attention also by physicists and engineers and will be considered in some more detail in the following sections.

\section{Water transport: the unbelievable tension pump of plants}

Flow in micro-tubes

The water stream inside a plant stem is carried by numerous conduits, the tracheids or vessels (the more modern conduit type) which are dead in the functional state, leaving only the lignified cell walls as conduit walls (Fig. 3a). The living cell content is removed at the end of maturity, to maximize conductance for water. The diameter of the conduits is in the $\mu \mathrm{m}$ range, with maximum sizes of several hundred $\mu \mathrm{m}$. Hydraulic conductance of the xylem is an important ecophysiological parameter which varies with species, organs (roots, stem, leaves) as well as with ontogenetic age. In the following, the more specific parameter "hydraulic conductivity" will be used which is the flow rate per pressure gradient whereas "hydraulic conductance" means the flow rate per pressure difference, meaning that "hydraulic conductivity" also includes the length of the transport pathway (Tyree and Ewers 1991).

Measurements of hydraulic conductivity of wood are conducted by letting water flow through a wood sample under a defined pressure and recording the volume flow rate (Sperry et al. 1988). This measurement is of course impossible for fossil wood, and a theoretical approach is necessary. Hydraulic conductivity of fossil xylem is obtained approximatively by Hagen-Poiseuille's law which describes flow through tubes 

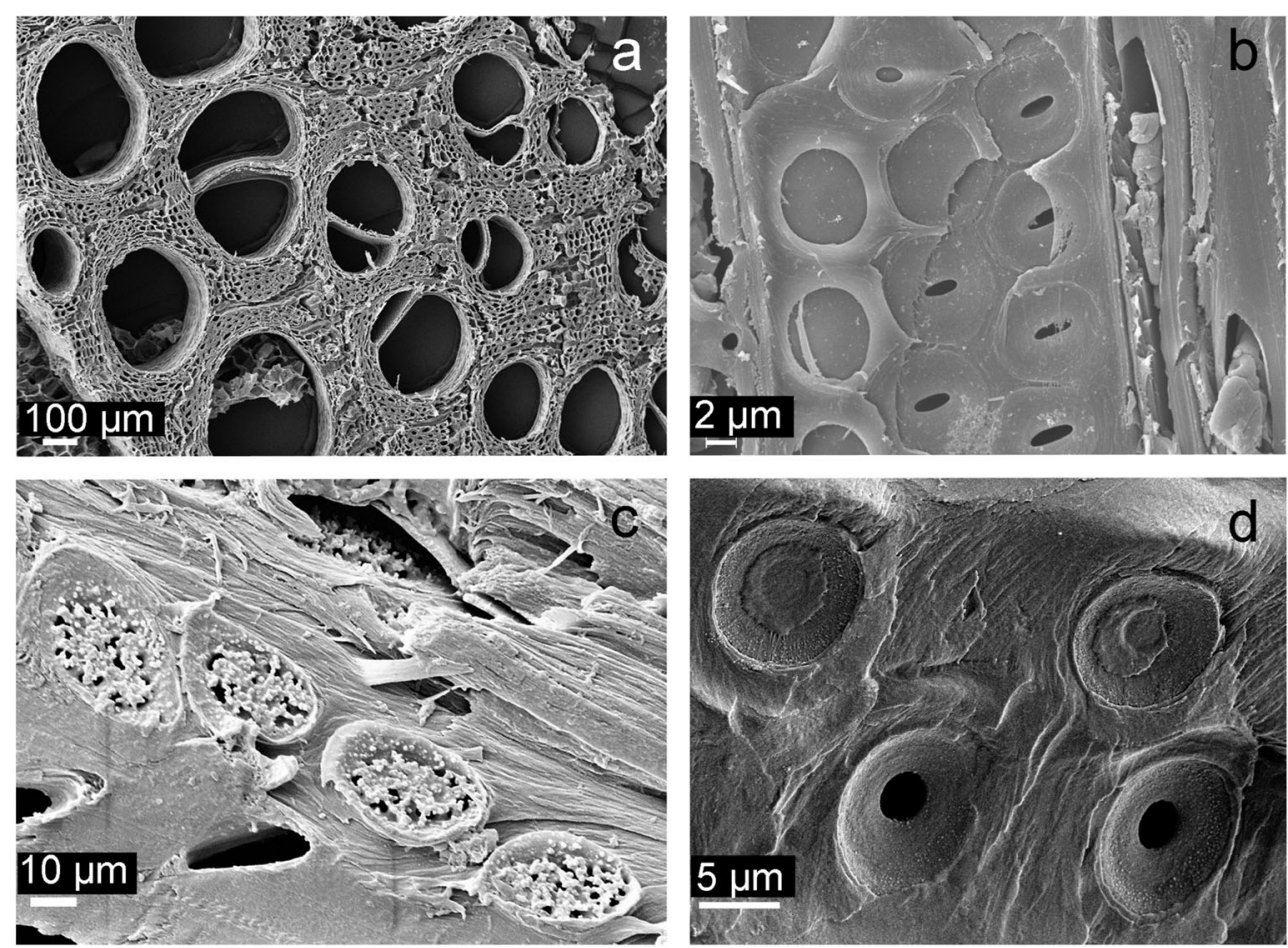

Fig. 3 Xylem conduits and pits. (a) Cross-section through the stem of the liana Adenia lobata, featuring large-sized vessels. (b) Vessel pits of Acer monspessulanum. The sample was prepared by longitudinal splitting. The pits at the left show complete pit membranes. (c) Vestured pits in the

(Niklas 1985; Wilson et al. 2008) and which is applicable to xylem conduits despite their narrow diameter (Leyton 1975).

The "standard" equation for the volume flow rate $Q\left[\mathrm{~m}^{3} / \mathrm{s}\right]$ through a tube (referring to a circular conduit cross-section with radius $r$ ) reads, according to Hagen-Poiseuille's law, as

$Q=\pi r^{4} \Delta p / 8 \mu l$

with $\mu=$ fluid viscosity [Pa s], $l=$ length of the transport path [m], $\Delta p=$ pressure difference along transport path [Pa].

To account for cross-sectional shapes different from a circle, such as elliptic or rectangular, various correction factors or adapted equations are available (Lewis and Boose 1995; Beebe et al. 2002).

As obvious from eq. (2), conduit size has a profound influence on transport capability, because it increases with the fourth power of radius. It is generally assumed that the evolution of vessels, which can become much wider than tracheids, was generally driven by water transport demand, allowing for much higher water transport rates with the same pressure gradient (Sperry 2003; Lucas et al. 2013). Vessels are restricted to angiosperms, with rare exceptions in extant (Gnetum (Carlquist 2012)) and fossil plants (Gigantopteridales (Li et al. 1996)) while conifers and spore bearing vascular plants show only tracheids. Although vessels appear to be superior to tracheids when water transport rates are considered, tracheids xylem of Faidherbia albida. (d) Bordered pits with tori in Pinus wallichiana. The upper two pits show pit membranes with tori which are aspirated, therefore sealing an embolized tracheid before sample preparation

very probably offer various niche-specific advantages (Pittermann and Sperry 2006; Hacke et al. 2015). Furthermore, crucial for water supply is the hydraulic conductivity of the entire wood cross-section, not that of a single conduit which is only a very small part of the conducting system. Lianas often feature large vessels, probably to compensate for the relatively small cross-sectional area (Fig. 3a) (Ewers et al. 1990).

The xylem consists of numerous single conduits and therefore represents a porous material, with the conduits as "very long pores". Flow through a porous material is described by Darcy's law, originally derived for flow through filter beds (Leyton 1975):

$Q=A K \Delta p / l$

with $A=$ cross-sectional area $\left[\mathrm{m}^{2}\right]$ of the material, $K=$ specific hydraulic conductivity $\left[\mathrm{m}^{2} / \mathrm{Pa} \mathrm{s}\right]$.

Hydraulic conductivity of a porous material (= reciprocal of hydraulic resistance) consisting of a number of small tubes depends on the size distribution of the tubes. If a porous material consists of tubes with identical size, its specific hydraulic conductivity can be easily derived from Hagen-Poiseuille's law (xylem consisting of conduits with different size classes requires more complex approaches (Cai and Tyree 2010)). Assume that the considered material 
consists of $n$ tubes, all with an identical radius $r$. The total flow rate through this material can then be calculated by using eq. (2):

$Q=n \pi r^{4} \Delta p / 8 \mu l$

Comparison of eqs. (3) and (4) allows the conclusion

$K=n \pi r^{4} / 8 \mu A$

Hydraulic conductivity of wood obtained by HagenPoiseuille's law represents the maximum possible value and is usually substantially higher compared with measured values (Lösch 2003). The reasons for this are overestimation of conduit size, complex distribution of different conduit sizes, resistance of end walls (meaning the resistance the transpiration stream has to overcome when flowing from one conduit to the other through pits) or dysfunctional conduits (due to, for example, embolism). The presence of dysfunctional conduits can be demonstrated by letting a dye flow through the sample, and functional conduits will become marked by staining. Calculating (potential) hydraulic conductivity of a dicot wood is quite a laborious task because it requires careful counting of vessels (Cai and Tyree 2010). Also, despite the smaller size of tracheids when compared with vessels, coniferous wood consisting of 'tightly packed' tracheids can achieve a similar total hydraulic conductivity as dicot wood which usually comprises a lower number of large-size vessels per cross-sectional area (Hacke et al. 2006), meaning that the low transport capacity of tracheids can be compensated by number. Also, coniferous torus-margo pits compensate to a certain degree for the smaller conduit radius of tracheids, because they show a lower pit resistance than dicot pits (Pittermann et al. 2005).

In early land plants, total xylem hydraulic conductivity tended to be low, due to narrow conduits as well as a low cross-sectional xylem area (although taxa with quite high hydraulic conductivity existed during the Early Devonian (Wilson and Fischer 2011; Strullu-Derrien et al. 2014) and increased during evolution (Niklas 1985). The wood of various taxa of the Carboniferous showed hydraulic conductivity ranges similar to that of modern seed plants (Wilson et al. 2008; Wilson and Knoll 2010; Wilson et al. 2017). Various specific methodologies are used to reconstruct xylem hydraulic conductivity for entire cross-sections or single conduits (Strullu-Derrien et al. 2014; Tanrattana et al. 2019), and the evaluation of water transport capacity is of high palaeoecophysiological importance, because the total hydraulic conductivity of the xylem is a crucial element for photosynthesis and productivity (Raven 2017). The reason for this connection is clear: high photosynthesis rates require high rates of gas exchange (meaning high stomatal conductance) and therefore high transpiration rates. In fact, maximum photosynthesis rates are positively correlated with xylem hydraulic conductivity in extant plants (Santiago et al. 2004). Atmospheric $\mathrm{CO}_{2}$ levels, however, have varied widely throughout the past, with consequences for plant gas exchange. For a certain stomatal conductance, photosynthesis depends on external $\mathrm{CO}_{2}$. For subambient to moderately elevated $\mathrm{CO}_{2}$, assimilation rate will increase with increasing $\mathrm{CO}_{2}$, and then become saturated with further increasing $\mathrm{CO}_{2}$ (Konrad et al. 2008; Franks et al. 2012). On the basis of the biochemical profile of the photosynthesis machinery, photosynthesis in early land plants of the Early Devonian will be saturated despite very low stomatal conductance (due to low stomatal density) (Raven 1984; Roth-Nebelsick and Konrad 2003). However, these conclusions are based on the typical biochemical profile of Rubisco (Ribulose-1,5-bisphosphate carboxylase/oxygenase) in extant $\mathrm{C}_{3}$ plants.

With respect to water transport performance, there are also other xylem traits to consider. When the water column inside the conduits is under negative pressure, the conduit walls will experience mechanical stress which may lead to implosion. The mechanical stress will scale positively with increasing negative pressure, and therefore, the amount of conduit wall reinforcement is expected to correlate with the "negative working pressure" which is typical for a taxon (Hacke et al. 2001). The required reinforcement for a certain negative pressure is obtained via wall thickness and depends - among other factors - on the (inner) diameter of the conduit: wider conduits need more reinforcement than narrower conduits. In fact, Hacke et al. (2001) showed that the ratio between conduit wall thickness and inner diameter scales with cavitation resistance, and therefore with the "typical mechanical load" exerted by tensile water (see following chapter). This result indicates that mechanical properties of xylem elements are related to a great extent to water transport, at least for vessels in angiosperm wood which are specialised for water transport, in contrast to conifer tracheids which fulfil both tasks, mechanical stabilisation of the tree as well as water transport.

Another important feature for water transport under negative pressure is the presence of pits (Fig. $3 \mathrm{~b}, \mathrm{c}$ and d). These are required to allow flow to occur from one conduit to another, thereby creating a network of conduits offering a threedimensional transport matrix (Tyree and Zimmermann 2002; Sperry et al. 2006). Pits represent non-lignified patches in the conduit wall not covered by secondary wall material. Furthermore, a pit membrane is present, consisting of the primary walls of both adjacent cells plus middle lamella. Interconduit pits are bordered, meaning that the pit membrane is overarched by the secondary wall which leaves a pit aperture in the middle. The overarching secondary wall part is the pit border, whereas the overarched space above the pit membrane is the pit chamber. If the secondary wall is thick, the pit aperture leads into a pit canal connecting conduit lumen and pit chamber. Different kinds of bordered pits exist, with various sizes, shapes and other traits, depending on plant group, taxon and also ontogenetic state of the xylem. For example, "vestured" pits feature outgrowths of the secondary wall region 
(Fig. 3c) (Jansen et al. 1998). Pits cause resistance to lateral flow, also termed "end wall resistance", which the water has to overcome when passing from one conduit to another. There is evidence that resistances of conduit lumen and end walls are coordinated, each contributing about $50 \%$ to total hydraulic resistance (Sperry et al. 2005). Hydraulic resistance (or conductivity) of conduit walls depends on pit density and size (Loepfe et al. 2007).

Conductive capacity of the xylem is therefore composed of different kinds of hydraulic conductivity: mainly the conduit lumen conductivity (the "tube conductivity" which can be calculated by Hagen-Poiseuille's law) and the conduit wall conductivity, consisting of pit membrane conductivity and the geometry, density and size of pits. There can be also some other sources of flow resistance, such as those caused by perforation plates (Schulte and Castle 1993; Ennos 2000; Lancashire and Ennos 2002; Christman and Sperry 2010). The xylem represents a complex anisotropic and hierarchically organised porous material, comprising different kinds and scales of porosity, with the pores of the pit membrane reaching into the nanometer scale. This complexity is the basis for the unique transport principle of tensile water realised in vascular plants.

\section{Tensile water and nano-valves}

Water transport driven by leaf transpiration can be described as a "suction pump". This means that the pressure at the transpiring leaves is lower than the water pressure at the tree base. This raises a serious physical problem, because to overcome gravity, a pressure gradient of $10^{5} \mathrm{~Pa}(\approx 1 \mathrm{~atm})$ is necessary for each $10 \mathrm{~m}$ of height. Just to reach a distance of $10 \mathrm{~m}$ above ground, the water pressure therefore has to arrive at zero. When the various resistances of the transport path, such as resistance within the soil or the root system, are taken into account, the water pressure will even become negative. From an engineering point of view, it is quite astounding that plants rely on this water transport principle, because these conditions are expected to be precarious, with the formation and rapid expansion of gas bubbles leading to conduit blockage by embolism as a major threat. The basic mechanism of long-distance transport of water is formulated by the cohesion-tension theory which has its origin already in the 19th century (Brown 2013). The core of the recent state of this theory is the "internal" cohesion between water molecules by hydrogen bonds and the adhesion of water molecules to the conduit walls, also by hydrogen bonds. These bonds allow a water body to be pulled like a rope and to develop - also like a rope - the tensile state which manifests itself by negative water pressure. This mechanism has fascinated engineers and physicists for a long time, sparking many debates (Venturas et al. 2017) and inspiring artificial constructions for water transport on the basis of the tensile state (Hayward 1970;
Hayward 1971; Tötzke 2008; Wheeler and Stroock 2008). Research on plant water transport has therefore a strong basis in thermodynamics and interfacial physics (Pickard 1981; Stroock et al. 2014; Konrad et al. 2018).

A major aspect of this transport mechanism is the metastability of tensile water, meaning the danger of embolism formation (gas filling the conduit lumen) leading to blockage of the conduits. There are two possibilities how gas can appear in xylem conduits being under negative pressure. The first one is cavitation, the expected formation of water vapor bubbles when the water pressure reaches - or even falling belowsaturation vapor pressure. Such de novo bubbles are the result of broken hydrogen bonds and the subsequent filling of the voids by water vapor ("boiling at room temperature"). The probability of such a spontaneous formation of gas bubbles depends on the circumstances. It can be calculated and is not to be expected to occur under conditions of plant water transport (Oertli 1971; Pickard 1981; Konrad et al. 2018). In fact, water can withstand quite substantially negative pressures before water vapor bubbles form spontaneously, as long as there are no pre-existing gas bodies or impurities (which are filtered out of the transpiration stream during the root passage) (Konrad et al. 2018). The real threat of embolism formation in xylem conduits is due to air bubbles, which somehow find their way into the tensile water column (Tyree and Zimmermann 2002). There are various sources of air which may enter xylem conduits, such as leaf abscission, damages or air being present at primary xylem sites (Choat et al. 2015).

The interconnectivity of conduits by pits is potentially fatal in case of embolism, because the gas filling an embolized conduit could spread unlimited over the entire xylem, making it completely dysfunctional within short time. It is therefore mandatory to contain embolism, preventing its easy spreading to adjacent conduits. Coniferous pits are able to act as "pressure valves" which seal a gas-filled tracheid. The typical coniferous pit membrane shows a peripheral part, termed margo, which is highly porous while its centre, termed torus, is substantially thickened. In case of an embolism event, tori are drawn towards the pit aperture, thereby sealing an embolized tracheid (Fig. 3d).

The sealing principle of other pit types is more complex. In angiosperms, pit membranes are more or less homogenous but much denser (Fig. 3b). In case of embolism, the pit membrane separates a liquid (water in the functional conduit) from air (filling the embolized neighbour). Inside each pit membrane pore, an interface develops between water and air. The pressure gradient between functional and dysfunctional conduit acts as a pulling force, trying to draw gas through the pit membrane pores, thereby stretching the menisci of these interfaces. The menisci are able to withstand the pulling force to a certain degree (the effect is an everyday experience when you are washing a $\mathrm{T}$-shirt, for example, and quite persistent air pockets form when the textile is immersed in water). 
To draw water through a pore, the required pressure difference $\Delta p$ rises with decreasing radius of the meniscus $r_{\mathrm{p}}$. This phenomenon is described by the Young-Laplace equation (with $\gamma=$ surface tension, and assuming full wettability of the pit membrane material):

$\Delta p=2 \gamma / r_{\mathrm{p}}$

With water having a surface tension of $\gamma \approx 0.07275 \mathrm{~N} / \mathrm{m}$, a pressure difference $\Delta p \approx 1 \mathrm{MPa}$ is necessary to draw water through the pore. This is, in fact, in the range of embolism resistance values found for mesophytic trees (Venturas et al. 2017).

Pit membranes of the 'non-margo' type therefore represent 'interface valves' and their functionality is of vital importance for plant water transport (Choat et al. 2003). The ability of pits to control embolism is reflected by the so-called "embolism resistance" or the maximum negative pressure a xylem can withstand. During the last years, a lot of research efforts were dedicated to this important aspect of xylem functionality which is based to a large degree on principles of interfacial physics. Accordingly, it is to be expected that pit structure affects embolism resistance, as was also found in various studies (Choat et al. 2004; Lens et al. 2011; Lens et al. 2013; Scholz et al. 2013; Li et al. 2016). Resistance to embolism is species-specific (although varying between individuals and ontogenetic states), depending on various factors. For example, in 'margo-torus' pits of conifer tracheids, minute holes can exist in the torus (Roth-Nebelsick et al. 2009), probably the remains of plasmodesmata, which affect embolism resistance (Jansen et al. 2012). Torus-like structures can also occur in angiosperms (Ohtani and Ishida 1978; Jansen et al. 2004; Dute et al. 2008; Dute et al. 2010a; Dute et al. 2010b), but only the margo of conifer tracheids shows the appearance of wheel spikes running from the pit margin to the torus. There is also some evidence that additional substances, particularly hydrogel-like ones, are involved, but this is under debate (Zwieniecki et al. 2001; Klepsch et al. 2016). Nanostructure of pit membranes as well as its chemical composition are of high interest to elucidate the interfacial processes occurring at pit membranes, but these are difficult to access and require sophisticated methods such as atomic force microscopy (Pesacreta et al. 2005; Lee et al. 2012).

\section{Trees as 'mini-biotopes'}

Conditions in the crown

The elaborate long-distance transport structures and principles described above are necessary to supply extensive canopy systems high above the forest floor. With increasing distance from the ground, air humidity decreases and wind velocity increases, leading to substantial differences between conditions close to the forest floor and those high up in the crown. The flow profile around trees depends, however, not only on tree height, but also on local conditions, such as regional topology and climate, as well as density and profile of the vegetation, with partially complex interactions (Coutts and Grace 1995). The microclimate within a tree crown depends therefore not only on its own architecture, but also on numerous other factors, including presence, height and structure of neighbouring trees (Madigosky 2004). Within a tree crown, the microclimate can vary considerably, with time as well as with position in the forest canopy. Wind velocity plays an important role, representing not only a formidable threat with respect to mechanical loading, but also affecting boundary layer conductance and leaf temperature along the canopy. Leaves at sun-exposed canopy sites experience fundamentally different conditions than leaves growing at more shaded positions, leading to the well-known phenomenon of "sun" and "shade" leaves, with the latter type larger and thinner than the first type (Lichtenthaler et al. 1981).

Leaf temperature and its dependence on environment are important when studying correlations of leaf traits and climate. Firstly, leaf temperature affects photosynthesis, because assimilation rate is highest under a certain optimum leaf temperature. Secondly, when leaf temperature exceeds a certain species-specific limit, thermal damage occurs. Thirdly, the water content of the leaf-internal air increases with temperature (warmer air shows - at a given relative humidity - a higher water content than cooler air), meaning that transpiration rate increases with leaf temperature with all other conditions being equal. Higher leaf temperature can therefore promote photosynthesis, but potentially rises water demand.

Larger objects which are heated will become warmer than smaller objects under the same conditions, because the boundary layer thickness rises with increasing object size. When exposed to a wind current, a warm object loses heat by convective cooling, and the rate of convective cooling rises with decreasing boundary layer thickness. Smaller objects will therefore show a higher heat removal than larger objects under the same conditions. The smaller size of sun leaves is therefore interpreted as strategy to limit the rise of leaf temperature and therefore to curb evaporative water loss. With the same reasoning, the often observed small leaf size of taxa living in habitats with low water availability is discussed as possible adaptation against leaf overheating and high transpiration rates. To estimate the effect of wind velocity and leaf size on leaf temperature, empirical equations from engineering sciences are used (Nobel 2005). To account for the size of the object, the "characteristic" dimension-expressed in length scale $[\mathrm{m}]$ - is applied. For example, for a rectangular plate, the characteristic dimension is the length of the plate in flow direction. However, these equations represent only rough approximations because they were derived with "ideal objects", 
meaning flat and smooth plates with standard shapes, such as discs and rectangles. Real leaves feature surface irregularities, such as protruding veins and hairs and show often quite complex shapes, leading to equivalently complex boundary layers and flow profiles (Schuepp 1993).

While lower air humidity and higher wind velocity are typical conditions experienced by forest canopies which easily cause water stress conditions for the leaves, a tree crown can also benefit from its height with respect to water supply "directly from the air", by intercepting atmospheric water (fog, mist, rain). The ecological importance of water absorption by leaves has become increasingly acknowledged over the last years and is considered to improve the water status particularly in arid environments or during drought when precipitation is low but fog or dew events are possible (Burgess and Dawson 2004; Breshears et al. 2008; Ebner et al. 2011; Eller et al. 2013; Binks et al. 2019). Fog and dew are two different events, with fog consisting of minute water droplets with sinking rates so low that they are floating in the wind whereas dew represents water condensed out of air at plant surfaces. In contrast to dew, fog consists of already condensed water droplets (in the range of 1-100 $\mu \mathrm{m}$ ) which are transported by wind. Dew requires the plant surface to be cooler than the surrounding moist air so that the point of oversaturation is reached.

The potential harvest rate of fog water increases with wind velocity and density and size of the fog droplets (Gandhidasan et al. 2018). Plant parts exposed to higher wind currents can therefore harvest potentially more fog water than plants closer to the ground. Together with various other plant species, the coniferous taxon Sequoia sempervirens, the coast redwood or Californian redwood, belonging to the tallest tree species, depends to a large degree on water supply by fog interception and absorption of the fog water by its needle leaves and also the bark (Burgess and Dawson 2004; Fischer et al. 2009; Limm and Dawson 2010; Mason Earles et al. 2016). In fact, the habitat of the Californian redwood is situated along the Pacific coast of North America, where fog frequently occurs, with the most northerly distribution in Oregon, and the most southerly in the region of the Monterey County.

Fog collection is also a topic of interest with respect to technical application (Klemm et al. 2012). Besides wind velocity and fog water content of the oncoming air, the structure of the intercepting objects is of importance. Interception rate will decline with increasing boundary layer thickness and an arrangement of small and narrow objects as fog-intercepting structure is therefore advantageous for fog collection. The density of the elements should be neither too high - which would inhibit the throughflow of fog-laden wind currentsnor too low-which would let a large amount air volume pass through without being "combed out" (Rivera 2011). Trees possessing small leaves and a spacious crown should therefore be able to intercept quite large amounts of fog. These considerations are also basic to optimal design of artificial fog collectors which are usually large screens consisting of thin filamentous elements or meshes mounted on a frame and erected at wind-exposed sites (Park et al. 2013; Holmes et al. 2015; Regalado and Ritter 2016).

Epiphytes-jewels in the crown

It is obvious that tree crowns represent special habitats of their own, offering ecological niches particularly to epiphytes. These "plants on plants" contribute substantially to species diversity of a forest and influence also productivity and hydrological processes (Zotz 2016) Fig. 4 a and b shows, as an example, the epiphyte-rich Atlantic rainforest of Southern Brazil. In contrast to trees, epiphytes satisfy their water demand from absorption of atmospheric water. Whereas this seems to represent a quite precarious life style, there are also various benefits. First and foremost, epiphytes are well supplied with light for photosynthesis without the demand to invest in tissues for mechanical stabilisation which is costly, contrary to self-supporting plants (also lianas which climb trees to reach the upper canopy require a large amount of stem material (Putz and Mooney 1991; dos Santos Miranda 2013)). On the other hand, conditions in the crown include quite high vapor pressure deficit during the day (Miranda et al. 2020), making efficient water uptake and storage essential for epiphytes to maintain a favourable water status. Special adaptations for the uptake of atmospheric water are an outstanding feature of many epiphytes, including both vascular and nonvascular taxa. It should be noted that research on epiphytes in their natural habitat requires often difficult working conditions in forests and the canopy (Fig. 4c). In the following, some brief examples for vascular epiphytes are presented.

Economic use of water is realised in many different ways. For water uptake, a variety of special traits can be observed for epiphytes. Leaves of tank bromeliads, for example, are arranged in a rosette-like manner in order to capture and store as much water as possible during rain events (Fig. 5a). Rhizomes of epiphytic ferns form a dense mesh to intercept water from stem flow running along the bark (Fig. 5b). Succulent leaves and pseudobulbs, such as shown in Fig. 5c, allow for a high capacity of water storage and are common features of epiphytic orchids. Furthermore, many epiphytes use CAM or $\mathrm{C}_{4}$ assimilation to achieve a high water use efficiency. Thick cuticles further reduce water loss by reducing epidermal transpiration - just to name a few adaptations to economic use of water.

Many epiphytes are able to exploit fog and dew as additional water sources. Dew formation occurs at plant surfaces during nights with high air humidity, when heat in form of infrared radiation is emitted, reducing the temperature of the plant surface to the condensation point. Utilisation of dew was observed for several plants living in arid environments (Hill et al. 2015) but is also reported from rainforest bromeliads 

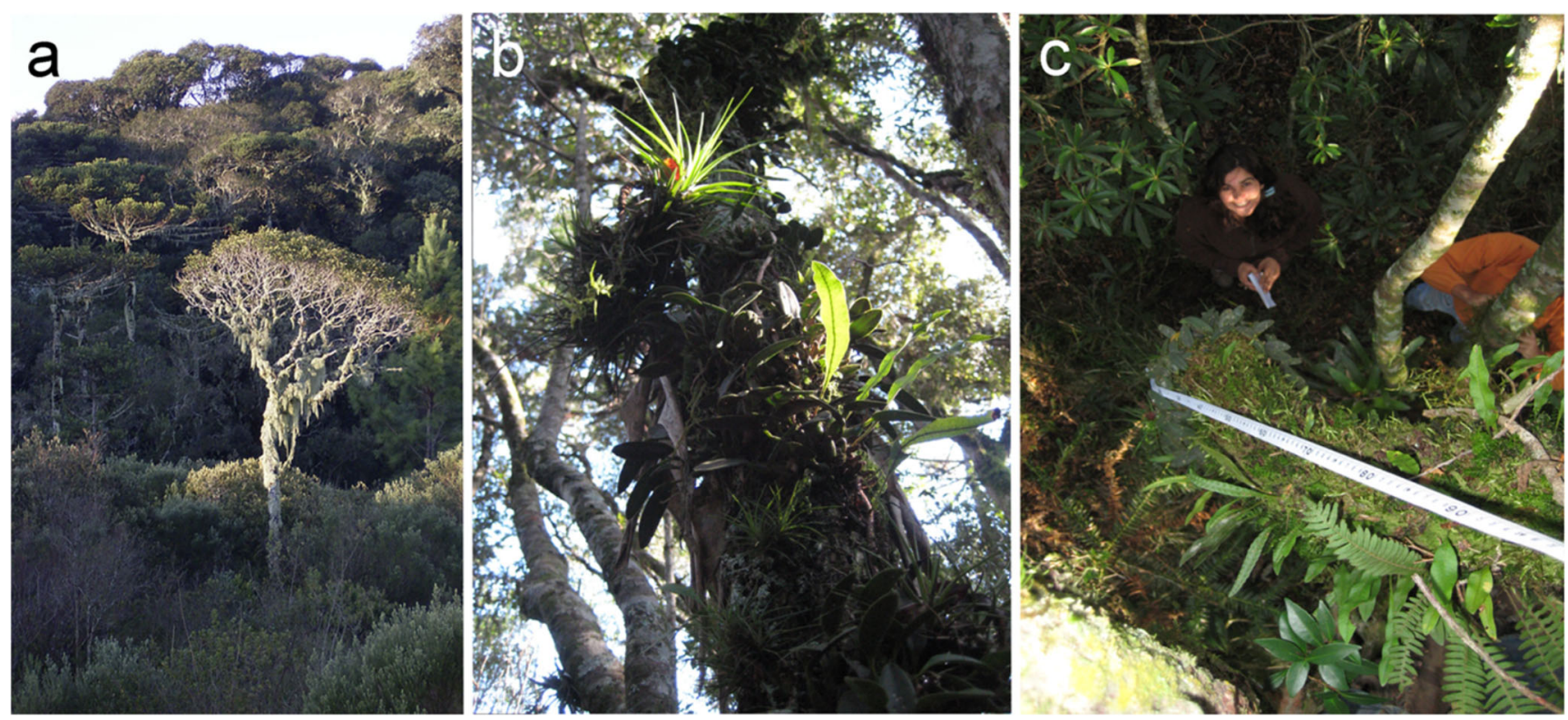

Fig. 4 Epiphytes on trees in the Atlantic rainforest of Southern Brazil. (a) Forest structure and landscape. (b) Tree trunk colonised by epiphytes. (c) Epiphyte monitoring

(Andrade 2003). As described in the preceding section, the boundary layer thickness decreases with wind velocity and increases with leaf size. Small (or narrow) leaves should therefore be particularly suitable for fog collection (Martorell and Ezcurra 2007). Species of the genus Tillandsia often feature long and narrow leaves (Fig. 6a). Since fog harvesting rate also depends on wind velocity, the detailed location in the crown is another essential factor: exposed plants should collect more fog than plants which are shielded from wind currents. To absorb atmospheric water swiftly, epiphytes show special surface structures with remarkable properties. In Bromeliads, and particularly in the genus Tillandsia, special trichomes are essential for intercepting and absorbing atmospheric water (Mez 1904; Benzing 1976; Benzing et al. 1978) (Fig. 6b). These multicellular trichomes, termed absorptive scales, respond to wetting by opening pores for water
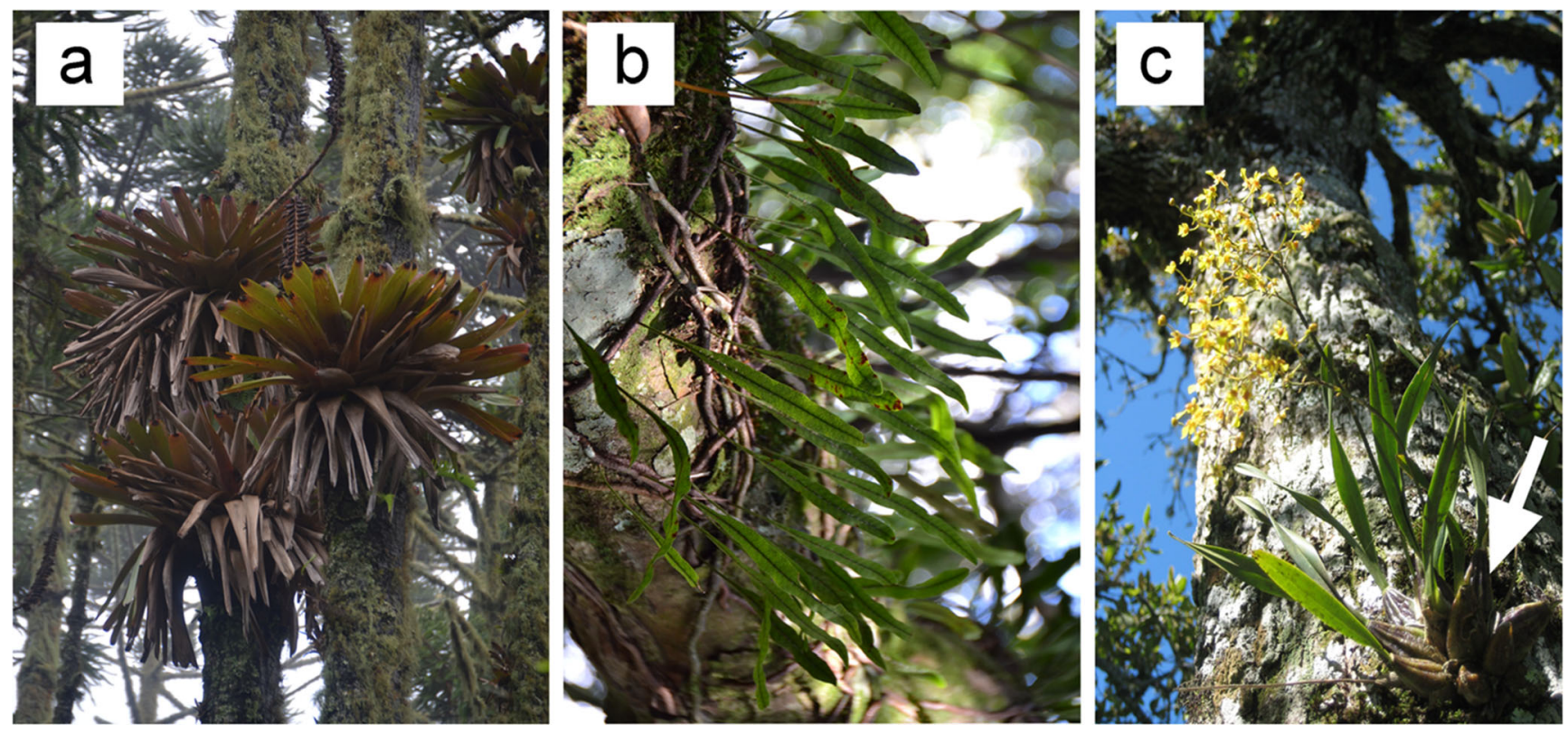

Fig. 5 Epiphytes of the Southern Brazilian Mata Atlântica featuring different strategies for water supply. (a) The tank bromeliad Aechmea sp. with leaf rosettes forming a water reservoir to collect rain water. (b)
Dense mesh of rhizomes of Microgramma sp., a fern, covering the bark of its host tree to collect water from stemflow. (c) Water-storing pseudobulbs of the orchid Gomesa concolor 

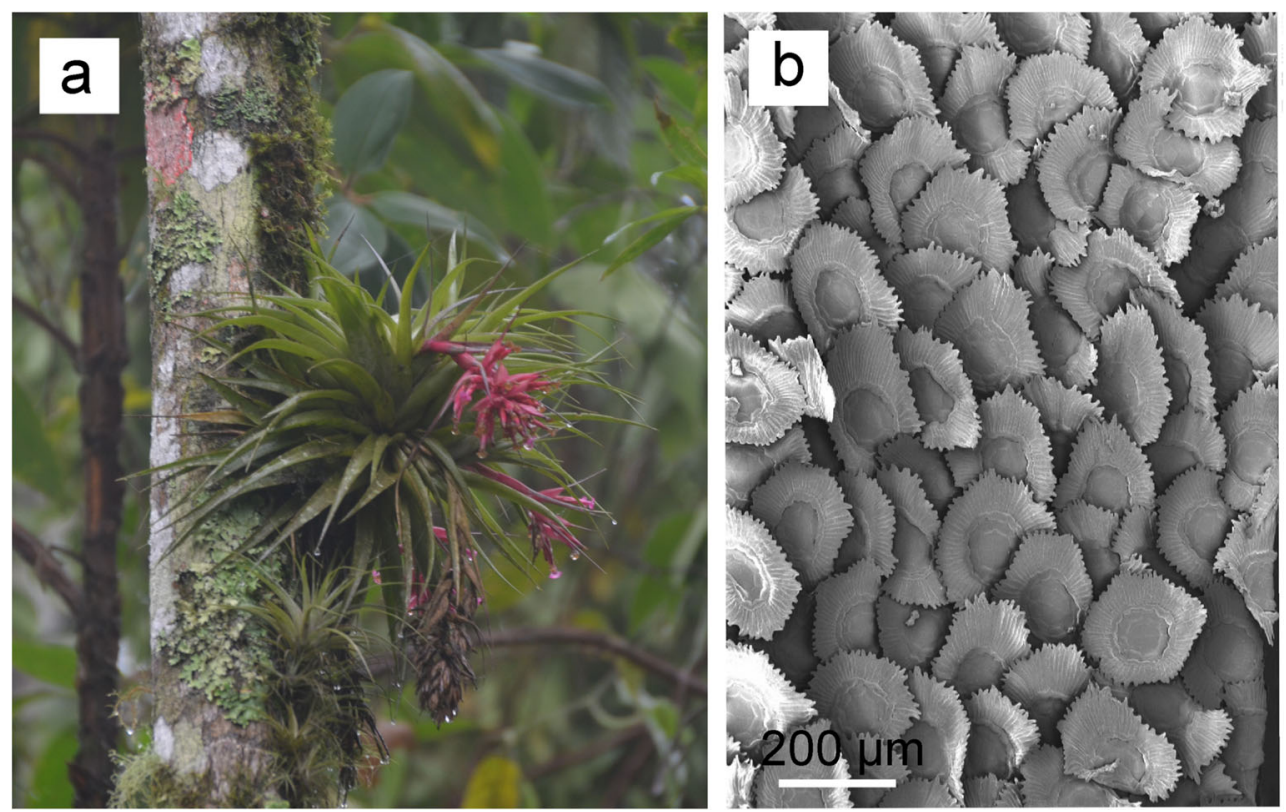

Fig. 6 Epiphytic bromeliad Tillandsia geminiflora (a) showing leaves densely covered with absorptive scales (b)

absorption (Benzing 1976) and forming a capillary structure with excellent ability for external water conduction (Herppich et al. 2019). When the surface becomes dry again, the pore is closed, preventing water loss by evaporation. The dry state is indicated by a silvery appearance, due to total reflection of light by the dead trichomes. In epiphytic orchids, a special external layer around the aerial roots, the velamen radicum, is responsible for water absorption (Zotz and Hietz 2001).

On the basis of all these special adaptations serving to become independent from soil water, epiphytes are able to colonise tree canopies. The rich diversity and biomass of epiphytes settling in tree crowns create habitats of their own, providing environmental space for numerous other organisms, such as the well-known use of filled bromeliad tanks by treefrogs (Alves-Silva and da Silva 2009; Romero et al. 2010). Tree-crowns therefore represent "mini-biotopes" contributing substantially to biodiversity and to ecological cycles by adding environmental space above ground, made possible by the mechanical qualities of tree stems. This is not only true for tropical environments. In cooler climates, trees are also colonised by epiphytic organisms, particularly mosses, and represent important habitats for animals, by offering dwellings, nesting possibilities and food sources.

Today, about $9 \%$ of all vascular land plant species are epiphytes, with partially high radiation rates (Zotz 2016). Epiphytes of the Atlantic Forest, for example, radiated recently in the Pliocene (Ramos et al. 2019). The fossil record of vascular epiphytes is quite sparse, requiring sites with exceptional preservation, and available information on fossil material indicates that early vascular epiphytes were usually represented by ferns (Poole and Page 2000; Psenicka and Oplustil 2013). Probably, the ability to develop considerable resilience against drought was an important factor that enabled ferns to evolve into the epiphytic niche (Pittermann et al. 2013; Niinemets et al. 2018). Given the high ecological importance of extant epiphytes, it appears desirable to obtain more knowledge on fossil epiphytes and the evolution of the epiphytic life style.

\section{Conclusions}

Functional analysis of the tree habit on the level of the underlying physical principles has proven to be outstandingly rewarding. This topic is also rewarding for engineering sciences and physics as it allows for exploring a rich constructional space which includes a variety of structures and how these structures are integrated into a larger multifunctional system. Functional analysis of trees, their tissues and cell structures is still a rich field of research with a high potential for solving long-standing questions as well as for novel discoveries and new concepts. For example, it is still under debate whether the maximum height of trees is limited by mechanics or hydraulics or possibly by other factors (Koch et al. 2004a; Niklas 2007; Munné-Bosch 2018; Williams et al. 2019). The study of fossil plants is exceptional in this respect, because the analysis has to be based on already available knowledge on plant tissues and their properties with measurements and experiments being impossible. Reconstructions of fossil plants can expand our information on the morphospace of possible biological constructions, on the basis of characteristics of plant materials, tissues and functional principles. With respect to fossil trees and their evolution, ongoing research provides a steady accumulating wealth of new results, unraveling the fossil record of the 
evolution of the tree habit to an ever finer and more detailed picture (Meyer-Berthaud et al. 2010; Chomicki et al. 2017).

In this context, new results on tissue structure and constructional principles of extant trees are important to understand the functional background of tree evolution and to obtain a comprehensive and integrative picture of the life style of fossil trees and their productivity (Decombeix et al. 2017; Wilson et al. 2017; Dambreville et al. 2018). This includes also evolutionary processes resulting in the tree habit. Phylogenetic analyses show that different growth forms can evolve quite rapidly within lineages (Isnard et al. 2012). Integrative approaches which combine the fossil record and phylogenetic analyses with studies on structure, function and ecology are fruitful in understanding the evolution of the tree habit and other growth forms and the underlying biotic and abiotic selective forces (Petit and Hampe 2006; Read and Stokes 2006; Isnard et al. 2012).

With respect to the function of water conduction, pit traits have increasingly come into focus due to their importance for resistance to embolism (Wheeler et al. 2005; Lens et al. 2013; $\mathrm{Mrad}$ et al. 2018). Ongoing research on the relationships between xylem structure and susceptibility to embolism contributes essentially to the understanding of tree resilience to drought which is highly important in a global context (Skelton et al. 2015; Nardini et al. 2017). Such results are also essential to evaluate the water economy of fossil trees and its ecophysiological consequences (Wilson and Knoll 2010; Wilson et al. 2017), with far-reaching implications for Earth's history.

Acknowledgements We thank two anonymous reviewers for their helpful and constructive comments. We also thank James Nebelsick (University of Tübingen) for valuable remarks and critically reading the English manuscript. We are also grateful for the invitation to contribute to this special issue by the guest-editors Angela Bruch, Dieter Uhl and Torsten Utescher.

Funding Open Access funding enabled and organized by Projekt DEAL.

\section{Compliance with ethical standards}

Conflict of interest The authors declare that they have no conflict of interest.

Open Access This article is licensed under a Creative Commons Attribution 4.0 International License, which permits use, sharing, adaptation, distribution and reproduction in any medium or format, as long as you give appropriate credit to the original author(s) and the source, provide a link to the Creative Commons licence, and indicate if changes were made. The images or other third party material in this article are included in the article's Creative Commons licence, unless indicated otherwise in a credit line to the material. If material is not included in the article's Creative Commons licence and your intended use is not permitted by statutory regulation or exceeds the permitted use, you will need to obtain permission directly from the copyright holder. To view a copy of this licence, visit http://creativecommons.org/licenses/by/4.0/.

\section{References}

Alves-Silva, R., \& da Silva, H. R. (2009). Life in bromeliads: reproductive behaviour and the monophyly of the Scinax perpusillus species group (Anura: Hylidae). Journal of Natural History, 43(3-4), 205217.

Andrade, J. L. (2003). Dew deposition on epiphytic bromeliad leaves: an important event in a Mexican tropical dry deciduous forest. Journal of Tropical Ecology, 19, 479-488.

Bateman, R. M., Crane, P. R., DiMichele, W. A., Kenrick, P., Rowe, N. P., Speck, T., et al. (1998). Early evolution of land plants: phylogeny, phyiology, and ecology of the primary terrestrial radiation. Annual Review of Ecology and Systematics, 29, 263-292.

Beebe, D. J., Mensing, G. A., \& Walker, G. M. (2002). Physics and applications of microfluidics in biology. Annual Review of Biomedical Engineering, 4, 261-286.

Beerling, D. J., \& Fleming, A. J. (2007). Zimmermann's telome theory of megaphyll leaf evolution: a molecular and cellular critique. Current Opinion in Plant Biology, 10(1), 4-12.

Benzing, D. (1976). The absorptive capacities of bromeliad trichomes. American Journal of Botany, 63, 1009-1014.

Benzing, D. H., Seemann, J., \& Renfrow, A. (1978). The foliar epidermis in Tillandsioideae (Bromeliaceae) and its role in habitat selection. American Journal of Botany, 65, 359-365.

Binks, O., Mencuccini, M., Rowland, L., da Costa, A. C. L., de Carvalho, C. J. R., Bittencourt, P., et al. (2019). Foliar water uptake in Amazonian trees: evidence and consequences. Global Change Biology, 25(8), 2678-2690. https://doi.org/10.1111/gcb.14666.

Blackman, C. J., Gleason, S. M., Cook, A. M., Chang, Y., Laws, C. A., \& Westoby, M. (2018). The links between leaf hydraulic vulnerability to drought and key aspects of leaf venation and xylem anatomy among 26 Australian woody angiosperms from contrasting climates. Annals of Botany, 122(1), 59-67.

Boyce, C. K., \& DiMichele, W. A. (2016). Arborescent lycopsid productivity and lifespan: constraining the possibilities. Review of Palaeobotany and Palynology, 227, 97-110.

Boyce, C. K., \& Knoll, A. H. (2002). Evolution of developmental potential and multiple independant origins of leaves in Paleozoic vascular plants. Paleobiology, 28, 70-100.

Boyce, C. K., Brodribb, T. J., Feild, T. S., \& Zwieniecki, M. A. (2009). Angiosperm leaf vein evolution was physiologically and environmentally transformative. Proceedings of the Royal Society of London B: Biological Sciences, 276(1663), 1771-1776. https://doi. org/10.1098/rspb.2008.1919.

Boyce, C. K., Lee, J.-E., Feild, T. S., Brodribb, T. J., \& Zwieniecki, M. A. (2010). Angiosperms helped put the rain in the rainforests: the impact of plant physiological evolution on tropical biodiversity. Annals of the Missouri Botanical Garden, 97(4), 527-541.

Born, L., Jonas, F. A., Bunk, K., Masselter, T., Speck, T., Knippers, J., et al. (2016). Branched structures in plants and architecture. In Biomimetic Research for Architecture and Building Construction (pp. 195-215): Springer.

Breshears, D. D., McDowell, N. G., Goddard, K. L., \& K.E., D., Martens, S. N., Meyer, C. W., et al. (2008). Foliar absorption of intercepted rainfall improves woody plant water status most during drought. Ecology, 89, 41- 47.

Brodersen, C. R., Lee, E. F., Choat, B., Jansen, S., Phillips, R. J., Shackel, K. A., et al. (2011). Automated analysis of three-dimensional xylem networks using high-resolution computed tomography. New Phytologist, 191(4), 1168-1179.

Brown, H. R. (2013). The theory of the rise of sap in trees: some historical and conceptual remarks. Physics in Perspective, 15(3), 320-358.

Burgess, S. S. O., \& Dawson, T. E. (2004). The contribution of fog to the water relations of Sequoia sempervirens (D. Don): foliar uptake and 
prevention of dehydration. Plant, Cell \& Environment, 27, 1023 1034.

Cai, J., \& Tyree, M. T. (2010). The impact of vessel size on vulnerability curves: data and models for within-species variability in saplings of aspen, Populus tremuloides Michx. Plant, Cell \& Environment, 33(7), 1059-1069.

Carlquist, S. (2012). Wood anatomy of Gnetales in a functional, ecological, and evolutionary context. Aliso: A Journal of Systematic and Evolutionary Botany, 30(1), 33-47.

Choat, B., Ball, M., Luly, J., \& Holtum, J. (2003). Pit membrane porosity and water stress-induced cavitation in four co-existing dry rainforest species. Plant Physiology, 131, 41-48.

Choat, B., Jansen, S., Zwieniecki, M. A., Smets, E., \& Holbrook, N. M. (2004). Changes in pit membrane porosity due to deflection and stretching: the role of vestured pits. Journal of Experimental Botany, 55, 1569-1575.

Choat, B., Brodersen, C. R., \& McElrone, A. J. (2015). Synchrotron Xray microtomography of xylem embolism in Sequoia sempervirens saplings during cycles of drought and recovery. New Phytologist, 205(3), 1095-1105. https://doi.org/10.1111/nph.13110.

Chomicki, G., Coiro, M., \& Renner, S. S. (2017). Evolution and ecology of plant architecture: integrating insights from the fossil record, extant morphology, developmental genetics and phylogenies. Annals of Botany, 120(6), 855-891.

Christman, M. A., \& Sperry, J. S. (2010). Single-vessel flow measurements indicate scalariform perforation plates confer higher flow resistance than previously estimated. Plant, Cell \& Environment, 33(3), 431-443.

Cichan, M. A. (1986). Vascular cambium and wood development in Carboniferous plants. III. Arthropitys (Equisetales; Calamitaceae). Canadian Journal of Botany, 64(3), 688-695.

Cichan, M. A., \& Taylor, T. N. (1983). A systematic and developmental analysis of Arthropitys deltoides sp. nov. Botanical Gazette, 144(2), 285-294.

Clair, B., Ghislain, B., Prunier, J., Lehnebach, R., Beauchêne, J., \& Alméras, T. (2019). Mechanical contribution of secondary phloem to postural control in trees: the bark side of the force. New Phytologist, 221(1), 209-217.

Cleal, C. J., \& Thomas, B. A. (2005). Palaeozoic tropical rainforests and their effect on global climates: is the past the key to the present? Geobiology, 3(1), 13-31.

Coutts, M., \& Grace, J. (1995). Wind and trees. Cambridge: Cambridge University Press.

Cramer, M. D., Hawkins, H.-J., \& Verboom, G. A. (2009). The importance of nutritional regulation of plant water flux. Oecologia, 161(1), 15-24.

Cui, J., Zhou, G., \& Ohsaki, M. (2016). Design of tree-type support structure of free-form shell generated using fractal geometry. Proceedings of IASS Annual Symposia, 8, 1-9.

Dambreville, A., Meyer-Berthaud, B., Barczi, J.-F., Decombeix, A.-L., Griffon, S., \& Rey, H. (2018). Chapter 3 - Using architecture modeling of the Devonian tree Pseudosporochnus to compute its biomass. In M. Krings, C. J. Harper, N. R. Cúneo, \& G. W. Rothwell (Eds.) Transformative Paleobotany (pp. 35-47): Academic Press.

Decombeix, A.-L., Meyer-Berthaud, B., \& Galtier, J. (2011). Transitional changes in arborescent lignophytes at the Devonian-Carboniferous boundary. Journal of the Geological Society, 168(2), 547-557. https://doi.org/10.1144/0016-76492010-074.

Decombeix, A.-L., Letellier, D., \& Meyer-Berthaud, B. (2017). Whose roots are these? Linking anatomically preserved lignophyte roots and stems from the early carboniferous of Montagne Noire, France. International Journal of Plant Sciences, 178(1), 42-56. https://doi.org/10.1086/689029.

DiMichele, W. A., \& Gastaldo, R. A. (2008). Plant paleoecology in deep time. Annals of the Missouri Botanical Garden, 95(1), 144-198 155. dos Santos Miranda, T. (2013). Water Relations of Lianas. PhD Thesis. Tübingen: University of Tübingen.

Dute, R., Patel, J., \& Jansen, S. (2010a). Torus-bearing pit membranes in Cercocarpus. IAWA Journal, 31(1), 53-66.

Dute, R., Rabaey, D., Allison, J., \& Jansen, S. (2010b). Torus-bearing pit membranes in species of Osmanthus. IAWA Journal, 31(2), 217 226.

Dute, R. R., Jansen, S., Holloway, C., \& Paris, K. (2008). Torus-bearing pit membranes in selected species of the Oleaceae. Journal of the Alabama Academy of Science, 79(1), 12-23.

Ebner, M., Miranda, T., \& Roth-Nebelsick, A. (2011). Efficient fog harvesting by Stipagrostis sabulicola (Namib dune bushman grass). Journal of Arid Environments, 75, 524-531. https://doi.org/10. 1016/j.jaridenv.2011.01.004.

Eggert, D., \& Kanemoto, N. (1977). Stem phloem of a middle Pennsylvanian Lepidodendron. Botanical Gazette, 138(1), 102111.

Eller, C. B., Lima, A. L., \& Oliveira, R. S. (2013). Foliar uptake of fog water and transport belowground alleviates drought effects in the cloud forest tree species, Drimys brasiliensis (Winteraceae). New Phytologist, 199(1), 151-162.

Ennos, A. (2000). The mechanics of root anchorage. Advances in Botanical Research, 33, 133-157.

Eshel, A., \& Beeckman, T. (2013). Plant roots: the hidden half: CRC press.

Ewers, F. W., Fisher, J. B., \& Chiu, S. T. (1990). A survey of vessel dimensions in stems of tropical lianas and other growth forms. Oecologia, 84, 544-552.

Fischer, D. T., Still, C. J., \& Williams, A. P. (2009). Significance of summer fog and overcast for drought stress and ecological functioning of coastal California endemic plant species. Journal of Biogeography, 36(4), 783-799.

Fisher, J. B., \& Mueller, R. J. (1983). Reaction anatomy and reorientation in leaning stems of balsa (Ochroma) and papaya (Carica). Canadian Journal of Botany, 61(3), 880-887. https://doi.org/10.1139/b83097.

Franks, P. J., Leitch, I. J., Ruszala, E. M., Hetherington, A. M., \& Beerling, D. J. (2012). Physiological framework for adaptation of stomata to $\mathrm{CO}_{2}$ from glacial to future concentrations. Philosophical Transactions of the Royal Society, B: Biological Sciences, 367(1588), 537-546.

Fratzl, P. (2007). Biomimetic materials research: what can we really learn from nature's structural materials? Journal of the Royal Society Interface, 4(15), 637-642.

Galtier, J. (2010). The origins and early evolution of the megaphyllous leaf. International Journal of Plant Sciences, 171(6), 641-661.

Gandhidasan, P., Abualhamayel, H. I., \& Patel, F. (2018). Simplified modeling and analysis of the fog water harvesting system in the Asir Region of the Kingdom of Saudi Arabia. Aerosol and Air Quality Research, 18(1), 200-213.

Geitmann, A., Niklas, K., \& Speck, T. (2019). Plant biomechanics in the 21st century. Journal of Experimental Botany, 70(14), 3435-3438. https://doi.org/10.1093/jxb/erz280.

Gorb, E. V., Baum, M. J., \& Gorb, S. N. (2013). Development and regeneration ability of the wax coverage in Nepenthes alata pitchers: a cryo-SEM approach. Scientific Reports, 3, 3078.

Hacke, U. G., Sperry, J. S., Pockman, W. T., Davis, S. D., \& McCulloh, K. A. (2001). Trends in wood density and structure are linked to prevention of xylem implosion by negative pressure. Oecologia, $126,457-461$.

Hacke, U. G., Sperry, J. S., Wheeler, J. K., \& Castro, L. (2006). Scaling of angiosperm xylem structure with safety and efficiency. Tree Physiology, 26, 689-701.

Hacke, U. G., Lachenbruch, B., Pittermann, J., Mayr, S., Domec, J.-C., \& Schulte, P. J. (2015). The hydraulic architecture of conifers. In U. 
Hacke (Ed.), Functional and Ecological Xylem Anatomy (pp. 3975). Cham: Springer International Publishing.

Harrison, C. J., \& Morris Jennifer, L. (2018). The origin and early evolution of vascular plant shoots and leaves. Philosophical Transactions of the Royal Society, B: Biological Sciences, 373(1739), 20160496. https://doi.org/10.1098/rstb.2016.0496.

Hayward, A. (1970). Mechanical pump with a suction lift of 17 metres. Nature, 225(5230), 376.

Hayward, A. T. (1971). Negative pressure in liquids: can it be harnessed to serve man? American Scientist, 59, 434-443.

Herppich, W. B., Martin, C. E., Tötzke, C., Manke, I., \& Kardjilov, N. (2019). External water transport is more important than vascular transport in the extreme atmospheric epiphyte Tillandsia usneoides (Spanish moss). Plant, Cell \& Environment, 42(5), 1645-1656.

Hesse, L., Leupold, J., Poppinga, S., Wick, M., Strobel, K., Masselter, T., et al. (2019). Resolving form-structure-function relationships in plants with MRI for biomimetic transfer. Integrative and Comparative Biology, 59(6), 1713-1726.

Hill, A. J., Dawson, T. E., Shelef, O., \& Rachmilevitch, S. (2015). The role of dew in Negev Desert plants. Oecologia, 178, 317-327.

Holmes, R., Rivera, J. D. D., \& de la Jara, E. (2015). Large fog collectors: New strategies for collection efficiency and structural response to wind pressure. Atmospheric Research, 151, 236-249. https://doi. org/10.1016/j.atmosres.2014.06.005.

Isnard, S., Prosperi, J., Wanke, S., Wagner, S. T., Samain, M.-S., Trueba, S., et al. (2012). Growth form evolution in Piperales and its relevance for understanding Angiosperm diversification: an integrative approach combining plant architecture, anatomy, and biomechanics. International Journal of Plant Sciences, 173(6), 610-639. https:// doi.org/10.1086/665821.

James, K. R., Dahle, G. A., Grabosky, J., Kane, B., \& Detter, A. (2014). Tree biomechanics literature review: Dynamics. Arboric. Urban Forum, 40, 1-15.

Jansen, S., Smets, E., \& Baas, P. (1998). Vestures in woody plants: a review. IAWA Journal, 19, 347-382.

Jansen, S., Choat, B., Vinckier, S., Lens, F., Schols, P., \& Smets, E. (2004). Intervascular pit membranes with a torus in the wood of Ulmus (Ulmaceae) and related genera. New Phytologist, 163(1), $51-59$.

Jansen, S., Lamy, J. B., Burlett, R., Cochard, H., Gasson, P., \& Delzon, S. (2012). Plasmodesmatal pores in the torus of bordered pit membranes affect cavitation resistance of conifer xylem. Plant, Cell \& Environment, 35(6), 1109-1120.

Jasechko, S., Sharp, Z. D., Gibson, J. J., Birks, S. J., Yi, Y., \& Fawcett, P. J. (2013). Terrestrial water fluxes dominated by transpiration. Nature, 496(7445), 347-350. https://doi.org/10.1038/nature11983.

Jensen, K. H., Liesche, J., Bohr, T., \& Schulz, A. (2012). Universality of phloem transport in seed plants. Plant, Cell \& Environment, 35(6), 1065-1076.

Kaack, L., Altaner, C. M., Carmesin, C., Diaz, A., Holler, M., Kranz, C., et al. (2019). Function and three-dimensional structure of intervessel pit membranes in angiosperms: a review. IAWA Journal, 40(4), 673-702.

Kempe, A., Lautenschläger, T., Lange, A., \& Neinhuis, C. (2014). How to become a tree without wood-biomechanical analysis of the stem of Carica papaya L. Plant Biology, 16(1), 264-271.

Kenrick, P., \& Crane, P. R. (1997). The origin and early diversification of land plants: a cladistic study. In Smithsonian Series in Comparative Evolutionary Biology. Washington, DC.: Smithsonian Institution Press.

Klemm, O., Schemenauer, R., Lummerich, A., Cereceda, P., Marzol, V., Corell, D., et al. (2012). Fog as a fresh-water resource: overview and perspectives. Ambio, 41(3), 221-234. https://doi.org/10.1007/ s13280-012-0247-8.
Klepsch, M. M., Schmitt, M., Paul Knox, J., \& Jansen, S. (2016). The chemical identity of intervessel pit membranes in Acer challenges hydrogel control of xylem hydraulic conductivity. AoB Plants, 8.

Knippers, J., Schmid, U., \& Speck, T. (2019). Biomimetics for architecture - learning from nature. Basel: Birkhäuser.

Koch, G. W., Sillett, S. C., Jennings, G. M., \& Davis, S. D. (2004a). The limits to tree height. Nature, 428(6985), 851-854.

Koch, K., Neinhuis, C., Ensikat, H. J., \& Barthlott, W. (2004b). Self assembly of epicuticular waxes on living plant surfaces imaged by atomic force microscopy (AFM). Journal of Experimental Botany, 55(397), 711-718.

Konrad, W., Katul, G., Roth-Nebelsick, A., \& Jensen, K. H. (2018). Xylem functioning, dysfunction and repair: a physical perspective and implications for phloem transport. Tree Physiology, 39(2), 243261.

Konrad, W., Roth-Nebelsick, A., \& Grein, M. (2008). Modelling of stomatal density response to atmospheric $\mathrm{CO}_{2}$. Journal of Theoretical Biology, 253, 638-658.

Kramer, P. (1983). The soil-plant-atmosphere continuum concept. In Water relations of plants. San Diego: Academic Press.

Kramer, P. J., \& Boyer, J. S. (1995). Water relations of plants and soils. New York: Academic Press.

Lancashire, J., \& Ennos, A. (2002). Modelling the hydrodynamic resistance of bordered pits. Journal of Experimental Botany, 53(373), $1485-1493$.

Larcher, W. (2003). Physiological plant ecology (4th ed.). Cambridge: Cambridge University Press.

Lee, J., Holbrook, N. M., \& Zwieniecki, M. A. (2012). Ion induced changes in the structure of bordered pit membranes. Frontiers in Plant Science, 3, 55.

Lens, F., Sperry, J. S., Christman, M. A., Choat, B., Rabaey, D., \& Jansen, S. (2011). Testing hypotheses that link wood anatomy to cavitation resistance and hydraulic conductivity in the genus Acer. New Phytologist, 190(3), 709-723.

Lens, F., Tixier, A., Cochard, H., Sperry, J. S., Jansen, S., \& Herbette, S. (2013). Embolism resistance as a key mechanism to understand adaptive plant strategies. Current Opinion in Plant Biology, 16(3), 287-292.

Lewis, A. M., \& Boose, E. R. (1995). Estimating volume flow rates through xylem conduits. American Journal of Botany, 82(9), 1112-1116. https://doi.org/10.1002/j.1537-2197.1995.tb11581.x.

Leyton, L. (1975). Fluid behaviour in biological systems. Oxford: Clarendon Press.

Li, H., Taylor, E. L., \& Taylor, T. N. (1996). Permian vessel elements. Science, 271(5246), 188-189.

Li, S., Lens, F., Espino, S., Karimi, Z., Klepsch, M., Schenk, H. J., et al. (2016). Intervessel pit membrane thickness as a key determinant of embolism resistance in angiosperm xylem. IAWA Journal, 37(2), $152-171$.

Lichtenthaler, H., Buschmann, C., Döll, M., Fietz, H.-J., Bach, T., Kozel, U., et al. (1981). Photosynthetic activity, chloroplast ultrastructure, and leaf characteristics of high-light and low-light plants and of sun and shade leaves. Photosynthesis Research, 2(2), 115-141.

Limm, E. B., \& Dawson, T. E. (2010). Polystichum munitum (Dryopteridaceae) varies geographically in its capacity to absorb fog water by foliar uptake within the redwood forest ecosystem. American Journal of Botany, 97(7), 1121-1128.

Loepfe, L., Martinez-Vilalta, J., Pinol, J., \& Mencuccini, M. (2007). The relevance of xylem network structure for plant hydraulic efficiency and safety. Journal of Theoretical Biology, 247(4), 788-803.

Lösch, R. (2003). Wasserhaushalt der Pflanzen. Wiebelsheim: Quelle \& Meyer.

Lucas, W. J., Groover, A., Lichtenberger, R., Furuta, K., Yadav, S.-R., Helariutta, Y., et al. (2013). The plant vascular system: evolution, development and functions. Journal of Integrative Plant Biology, 55(4), 294-388. https://doi.org/10.1111/jipb.12041. 
Madigosky, S. R. (2004). Tropical microclimatic considerations. In M. D. Lowman \& H. B. Rinker (Eds.) Forest Canopies (2nd ed., pp. 24 48). San Diego: Academic Press.

Manzoni, S., Vico, G., Porporato, A., \& Katul, G. (2013). Biological constraints on water transport in the soil-plant-atmosphere system. Advances in Water Resources, 51, 292-304.

Martorell, C., \& Ezcurra, E. (2007). The narrow-leaf syndrome: a functional and evolutionary approach to the form of fog-harvesting rosette plants. Oecologia, 151, 561-573.

Mason Earles, J., Sperling, O., Silva, L. C., McElrone, A. J., Brodersen, C. R., North, M. P., et al. (2016). Bark water uptake promotes localized hydraulic recovery in coastal redwood crown. Plant, Cell \& Environment, 39(2), 320-328.

Masselter, T., Kempe, A., Caliaro, S., Neinhuis, C., \& Speck, T. (2017). Comparing structure and biomechanics of extant Carica papaya and Ochroma pyramidale stems allows re-evaluating the functional morphology of the fossil 'seed fern' Lyginopteris oldhamia. Review of Palaeobotany and Palynology, 246, 258-263.

Menges, A., \& Reichert, S. (2015). Performative wood: physically programming the responsive architecture of the HygroScope and HygroSkin projects. Architectural Design, 85(5), 66-73. https:// doi.org/10.1002/ad.1956.

Meyer-Berthaud, B., Scheckler, S. E., \& Wendt, J. (1999). Archaeopteris is the earliest known modern tree. Nature, 398(6729), 700.

Meyer-Berthaud, B., Scheckler, S. E., \& Bousquet, J. L. (2000). The development of Archaeopteris: new evolutionary characters from the structural analysis of an Early Famennian trunk from southeast Morocco. American Journal of Botany, 87(4), 456-468.

Meyer-Berthaud, B., Soria, A., \& Decombeix, A.-L. (2010). The land plant cover in the Devonian: a reassessment of the evolution of the tree habit. Geological Society, London, Special Publications, 339(1), 59-70. https://doi.org/10.1144/sp339.6.

Mez, C. (1904). Physiologische Bromeliaceen-Studien I. Die WasserÖkonomie der extrem atmosphärischen Tillandsien. Jahrbuch der Wissenschaftichen Botanik, 40, 157-229.

Miranda, T., Roth-Nebelsick, A., Junginger, A., \& Ebner, M. (2020). Habitat conditions, spatial distribution and trichome morphology of different species of Tillandsia growing on trees on the Ilha Grande Island, Brazil. Flora, 272, 151692.

Morris, J. L., Leake, J. R., Stein, W. E., Berry, C. M., Marshall, J. E. A., Wellman, C. H., et al. (2015). Investigating Devonian trees as geoengineers of past climates: linking palaeosols to palaeobotany and experimental geobiology. Palaeontology, 58(5), 787-801. https:// doi.org/10.1111/pala.12185.

Mosbrugger, V. (1990). The tree habit in land plants (Vol. 28, Lecture Notes in Earth Sciences). Berlin, Heidelberg: Springer-Verlag.

Moulia, B. (2013). Plant biomechanics and mechanobiology are convergent paths to flourishing interdisciplinary research. Journal of Experimental Botany, 64(15), 4617-4633.

Mrad, A., Domec, J. C., Huang, C. W., Lens, F., \& Katul, G. (2018). A network model links wood anatomy to xylem tissue hydraulic behavior and vulnerability to cavitation. Plant, Cell \& Environment, 41(12), 2718-2730.

Müller, U., Gindl, W., \& Jeronimidis, G. (2006). Biomechanics of a branch-stem junction in softwood. Trees, 20(5), 643-648.

Munné-Bosch, S. (2018). Limits to tree growth and longevity. Trends in Plant Science, 23(11), 985-993.

Nardini, A., Savi, T., Trifilò, P., \& Gullo, M. A. L. (2017). Drought stress and the recovery from xylem embolism in woody plants (pp. 197231). Cham: Springer.

Niinemets, Ü., Bravo, L. A., \& Copolovici, L. (2018). Changes in photosynthetic rate and stress volatile emissions through desiccationrehydration cycles in desiccation-tolerant epiphytic filmy ferns (Hymenophyllaceae). Plant, Cell \& Environment, 41(7), 16051617.
Niklas, K. J. (1985). The evolution of tracheid diameter in early vascular plants and its implications on the hydraulic conductance of the primary xylem strand. Evolution, 39(5), 1110-1122.

Niklas, K. J. (1992). Plant biomechanics: an engineering approach to plant form and function: University of Chicago press.

Niklas, K. J. (1997). The evolutionary biology of plants. In the evolutionary biology of plants. Chicago, IL: University of Chicago.

Niklas, K. J. (2007). Maximum plant height and the biophysical factors that limit it. Tree Physiology, 27(3), 433-440.

Nobel, P. S. (2005). Physicochemical and environmental plant physiology (3rd ed.). Amsterdam: Elsevier Academic Press.

Oertli, J. J. (1971). The stability of water under tension in the xylem. Zeitschrift für Pflanzenphysiologie, 65, 195-209.

Ohtani, J., \& Ishida, S. (1978). Pit membrane with torus in dicotyledonous woods [angiosperm tree]. Journal of the Japanese Wood Research Society, 24, 673-675.

Park, K.-C., Chhatre, S. S., Srinivasan, S., Cohen, R. E., \& McKinley, G. H. (2013). Optimal design of permeable fiber network structures for fog harvesting. Langmuir, 29(43), 13269-13277.

Passioura, J. (1982). Water in the soil-plant-atmosphere continuum. Physiological plant ecology II (pp. 5-33). Cham: Springer.

Pesacreta, T. C., Groom, L. H., \& Rials, T. G. (2005). Atomic force microscopy of the intervessel pit membrane in the stem of Sapium sebiferum (Euphorbiaceae). IAWA Journal, 26(4), 397-426.

Petit, R. J., \& Hampe, A. (2006). Some evolutionary consequences of being a tree. Annual Review of Ecology, Evolution, and Systematics, 37, 187-214.

Pickard, W. F. (1981). The ascent of sap in plants. Progress in Biophysical and Molecular Biology, 37, 181-229.

Pittermann, J., \& Sperry, J. S. (2006). Analysis of freeze-thaw embolism in conifers. The interaction between cavitation pressure and tracheid size. Plant Physiology, 140(1), 374-382. https://doi.org/10.1104/pp. 105.067900.

Pittermann, J., Sperry, J. S., Hacke, U. G., Wheeler, J. K., \& Sikkema, E. H. (2005). Torus-margo pits help conifers compete with angiosperms. Science, 310(5756), 1924-1924.

Pittermann, J., Brodersen, C. B., \& Watkins Jr., J. (2013). The physiological resilience of fern sporophytes and gametophytes: advances in water relations offer new insights into an old lineage. Frontiers in Plant Science, 4, 285.

Poole, I., \& Page, C. N. (2000). A fossil fern indicator of epiphytism in a Tertiary flora. The New Phytologist, 148(1), 117-125.

Poppinga, S., \& Speck, T. (2019). Bark, the neglected tree postural motor system. New Phytologist, 221(1), 7-9.

Psenicka, J., \& Oplustil, S. (2013). The epiphytic plants in the fossil record and its example from in situ tuff from Pennsylvanian of Radnice Basin (Czech Republic). Bulletin of Geosciences, 88(2), 401-416.

Putz, F. E., \& Mooney, H. A. (1991). The biology of vines. Cambridge: Cambridge University Press.

Ramos, F. N., Mortara, S. R., Monalisa-Francisco, N., Elias, J. P. C., Neto, L. M., Freitas, L., et al. (2019). ATLANTIC EPIPHYTES: a data set of vascular and non-vascular epiphyte plants and lichens from the Atlantic Forest. Ecology, 100(2), e2541.

Raven, J. A. (1984). Physiological correlates of the morphology of early vascular plants. Botanical Journal of the Linnean Society, 88, 105126.

Raven, J. A. (2017). Evolution and palaeophysiology of the vascular system and other means of long-distance transport. Philosophical Transactions of the Royal Society, B: Biological Sciences, 373(1739), 20160497.

Raven, J. A., \& Edwards, D. (2014). Photosynthesis in early land plants: adapting to the terrestrial environment. In D. T. Hanson \& S. K. Rice (Eds.) Advances in Photosynthesis and Respiration (pp. 29-58). Dordrecht: Springer. 
Read, J., \& Stokes, A. (2006). Plant biomechanics in an ecological context. American Journal of Botany, 93(10), 1546-1565. https://doi. org/10.3732/ajb.93.10.1546.

Regalado, C. M., \& Ritter, A. (2016). The design of an optimal fog water collector: a theoretical analysis. Atmospheric Research, 178, 45-54.

Rivera, J.d D. (2011). Aerodynamic collection efficiency of fog water collectors. Atmospheric Research, 102(3), 335-342. https://doi. org/10.1016/j.atmosres.2011.08.005.

Rockwell, F. E., Holbrook, N. M., \& Stroock, A. D. (2014). The competition between liquid and vapor transport in transpiring leaves. Plant Physiology, 164(4), 1741-1758.

Romero, G. Q., Nomura, F., Gonçalves, A. Z., Dias, N. Y., Mercier, H., \& Conforto, E. d. C., et al. (2010). Nitrogen fluxes from treefrogs to tank epiphytic bromeliads: an isotopic and physiological approach. Oecologia, 162(4), 941-949.

Rößler, R. (2000). The late Palaeozoic tree fern Psaronius - an ecosystem unto itself. Review of Palaeobotany and Palynology, 108(1-2), $55-74$.

Roth-Nebelsick, A., \& Konrad, W. (2003). Assimilation and transpiration capabilities of rhyniophytic plants from the Lower Devonian and their implications for paleoatmospheric $\mathrm{CO}_{2}$ concentration. Palaeogeography, Palaeoclimatology, Palaeoecology, 202(1-2), 153-178. https://doi.org/10.1016/S0031-0182(03)00634-5.

Roth-Nebelsick, A., Uhl, D., Mosbrugger, V., \& Kerp, H. (2001). Evolution and function of leaf venation architecture: a review. Annals of Botany, 87(5), 553-566. https://doi.org/10.1006/anbo. 2001.1391.

Roth-Nebelsick, A., Voigt, D., \& Gorb, S. (2009). Cryo-scanning electron microscopy studies of pits in Pinus wallichiana and Mallotus japonicus. IAWA Journal, 31, 257-267.

Rowe, N., \& Speck, T. (2005). Plant growth forms: an ecological and evolutionary perspective. New Phytologist, 166(1), 61-72.

Sack, L., Buckley, T. N., \& Scoffoni, C. (2016). Why are leaves hydraulically vulnerable? Journal of Experimental Botany, 67(17), 4917.

Sack, L., \& Scoffoni, C. (2013). Leaf venation: structure, function, development, evolution, ecology and applications in the past, present and future. New Phytologist, 198(4), 983-1000. https://doi.org/10. 1111/nph.12253.

Santiago, L. S., Goldstein, G., Meinzer, F. C., Fisher, J. B., Machado, K., Woodruff, D., et al. (2004). Leaf photosynthetic traits scale with hydraulic conductivity and wood density in Panamanian forest canopy trees. Oecologia, 140, 543-550.

Scholz, A., Rabaey, D., Stein, A., Cochard, H., Smets, E., \& Jansen, S. (2013). The evolution and function of vessel and pit characters with respect to cavitation resistance across 10 Prunus species. Tree Physiology, 33(7), 684-694.

Schuepp, P. H. (1993). Tansley Review No. 59. Leaf boundary layers. New Phytologist, 125, 477-507.

Schulte, P. J., \& Castle, A. L. (1993). Water flow through vessel perforation plates-a fluid mechanical approach. Journal of Experimental Botany, 44(7), 1135-1142.

Schwager, H., Haushahn, T., Neinhuis, C., Speck, T., \& Masselter, T. (2010). Principles of branching morphology and anatomy in arborescent monocotyledons and columnar cacti as concept generators for branched fiber-reinforced composites. Advanced Engineering Materials, 12(12), B695-B698.

Skelton, R. P., West, A. G., \& Dawson, T. E. (2015). Predicting plant vulnerability to drought in biodiverse regions using functional traits. Proceedings of the National Academy of Sciences, 112(18), 5744 5749. https://doi.org/10.1073/pnas.1503376112.

Speck, T., \& Burgert, I. (2011). Plant stems: functional design and mechanics. Annual Review of Materials Research, 41, 169-193.

Speck, T., Bold, G., Masselter, T., Poppinga, S., Schmier, S., Thielen, M., et al. (2018). Biomechanics and functional morphology of plantsinspiration for biomimetic materials and structures. In Plant Biomechanics (pp. 399-433): Springer.
Sperry, J. S. (2003). Evolution of water transport and xylem structure. International Journal of Plant Sciences, 164, S115-S127.

Sperry, J. S., Donelly, J. R., \& Tyree, M. T. (1988). A method for measuring hydraulic conductivity and embolism in xylem. Plant, Cell \& Environment, 11, 35-40.

Sperry, J. S., Stiller, V., \& Hacke, U. G. (2003). Xylem hydraulics and the soil-plant-atmosphere continuum. Agronomy Journal, 95(6), 1362-1370.

Sperry, J. S., Hacke, U. G., \& Wheeler, J. K. (2005). Comparative analysis of end wall resistivity in xylem conduits. Plant, Cell \& Environment, 28(4), 456-465.

Sperry, J. S., Hacke, U. G., \& Pittermann, J. (2006). Size and function in conifer tracheids and angiosperm vessels. American Journal of Botany, 93(10), 1490-1500.

Spindler, F., Werneburg, R., Schneider, J. W., Luthardt, L., Annacker, V., \& Rößler, R. (2018). First arboreal 'pelycosaurs' (Synapsida: Varanopidae) from the early Permian Chemnitz Fossil Lagerstätte, SE Germany, with a review of varanopid phylogeny. PalZ, 92(2), 315-364.

Stein, W. E., Berry, C. M., Hernick, L. V., \& Mannolini, F. (2012). Surprisingly complex community discovered in the mid-Devonian fossil forest at Gilboa. Nature, 483(7387), 78.

Stein, W. E., Berry, C. M., Morris, J. L., Hernick, L. V., Mannolini, F., Ver Straeten, C., et al. (2020). Mid-Devonian Archaeopteris roots signal revolutionary change in earliest fossil forests. Current Biology, 30(3), 421-431. e422.

Stroock, A. D., Pagay, V. V., Zwieniecki, M. A., \& Michele Holbrook, N. (2014). The physicochemical hydrodynamics of vascular plants. Annual Review of Fluid Mechanics, 46(1), 615-642. https://doi. org/10.1146/annurev-fluid-010313-141411.

Strullu-Derrien, C., Kenrick, P., Tafforeau, P., Cochard, H., Bonnemain, J.-L., Le Hérissé, A., et al. (2014). The earliest wood and its hydraulic properties documented in c. 407-million-year-old fossils using synchrotron microtomography. Botanical Journal of the Linnean Society, 175(3), 423-437.

Tanner, W., \& Beevers, H. (2001). Transpiration, a prerequisite for longdistance transport of minerals in plants? Proceedings of the National Academy of Sciences, 98(16), 9443-9447.

Tanrattana, M., Barczi, J.-F., Decombeix, A.-L., Meyer-Berthaud, B., \& Wilson, J. (2019). A new approach for modelling water transport in fossil plants. IAWA Journal, 40, 466-487.

Tötzke, C. (2008). Untersuchungen über den Zustand tensilen Wassers in Bäumen. PhD thesis. Freie Universität Berlin, Berlin.

Tyree, M. T., \& Ewers, F. W. (1991). The hydraulic architecture of trees and other woody plants. New Phytologist, 119(3), 345-360.

Tyree, M. T., \& Zimmermann, M. H. (2002). Xylem structure and the ascent of sap. Berlin, Heidelberg, New York: Springer.

Vasco, A., Smalls, T. L., Graham, S. W., Cooper, E. D., Wong, G. K. S., Stevenson, D. W., et al. (2016). Challenging the paradigms of leaf evolution: class III HD-Zips in ferns and lycophytes. New Phytologist, 212(3), 745-758.

Venturas, M. D., Sperry, J. S., \& Hacke, U. G. (2017). Plant xylem hydraulics: what we understand, current research, and future challenges. Journal of Integrative Plant Biology, 59(6), 356-389.

Wegst, U. G., Bai, H., Saiz, E., Tomsia, A. P., \& Ritchie, R. O. (2015). Bioinspired structural materials. Nature Materials, 14(1), 23.

Wheeler, J. K., Sperry, J. S., Hacke, U. G., \& Hoang, N. (2005). Intervessel pitting and cavitation in woody Rosaceae and other vesselled plants: a basis for a safety versus efficiency trade-off in xylem transport. Plant, Cell \& Environment, 28, 800-812.

Wheeler, T. D., \& Stroock, A. D. (2008). The transpiration of water at negative pressures in a synthetic tree. Nature, 455, 209-212.

Williams, C. B., Anfodillo, T., Crivellaro, A., Lazzarin, M., Dawson, T. E., \& Koch, G. W. (2019). Axial variation of xylem conduits in the Earth's tallest trees. Trees, 33(5), 1299-1311. 
Wilson, J. P., \& Fischer, W. W. (2011). Hydraulics of Asteroxylon mackei, an early Devonian vascular plant, and the early evolution of water transport tissue in terrestrial plants. Geobiology, 9(2), 121130.

Wilson, J. P., \& Knoll, A. H. (2010). A physiologically explicit morphospace for tracheid-based water transport in modern and extinct seed plants. Paleobiology, 36(2), 335-355.

Wilson, J. P., Knoll, A. H., Holbrook, N. M., \& Marshall, C. R. (2008). Modeling fluid flow in Medullosa, an anatomically unusual Carboniferous seed plant. Paleobiology, 34(4), 472-493.

Wilson, J. P., Montañez, I. P., White, J. D., DiMichele, W. A., McElwain, J. C., Poulsen, C. J., et al. (2017). Dynamic Carboniferous tropical forests: new views of plant function and potential for physiological forcing of climate. New Phytologist, 215(4), 1333-1353.

Yamamoto, H., Kojima, Y., Okuyama, T., Abasolo, W., \& Gril, J. (2002). Origin of the biomechanical properties of wood related to the fine structure of the multi-layered cell wall. Journal of Biomechanical Engineering, 124(4), 432-440.

Zotz, G. (2016). Plants on plants - the biology of vascular epiphytes: Springer Nature.

Zotz, G., \& Hietz, P. (2001). The physiological ecology of vascular epiphytes: current knowledge, open questions. Journal of Experimental Botany, 52, 2067-2078.

Zwieniecki, M. A., Melcher, P. J., \& Holbrook, N. M. (2001). Hydrogel control of xylem hydraulic resistance in plants. Science, 291, 1059 1062.

Publisher's note Springer Nature remains neutral with regard to jurisdictional claims in published maps and institutional affiliations. 